\section{Mathematics standards and curricula in the Netherlands}

Marja van den Heuvel-Panhuizen \& Monica Wijers, Utrecht (the Netherlands)

\begin{abstract}
This paper addresses the question of what mathematics Dutch students should learn according to the standards as established by the Dutch Ministry of Education. The focus is on primary school and the foundation phase of secondary school. This means that the paper covers the range from kindergarten to grade 8 (4-14 years olds). Apart from giving an overview of the standards, we also discuss the standards' nature and history. Furthermore, we look at textbooks and examination programs that in the Netherlands both have a key role in determining the intended mathematics curriculum. In addition to addressing the mathematical content, we also pay attention to the way mathematics is taught. The domain-specific education theory that forms the basis for the Dutch approach to teaching mathematics is called "Realistic Mathematics Education." Achievement scores of Dutch students from national and international tests complete this paper. These scores reveal what the standards bring us in terms of students' mathematical understanding. In addition to informing an international audience about the Dutch standards and curricula, we include some critical reflections on them.
\end{abstract}

Kurzreferat: Dieser Beitrag setzt sich mit den niederländischen Standards und Curricula für den Mathematikunterricht auseinander, mit denen das Bildungsministerium festlegt, welche Mathematik Schülerinnen und Schüler in den Niederlanden lernen sollen. Dabei werden vor allem die Primarstufe und die beiden ersten Jahre der Sekundarstufe in den Blick genommen. Aufgrund der Struktur des niederländischen Schulsystems decken wir damit den Bereich von der vorschulischen Bildung im Kindergarten bis zum 8. Schuljahr ab (dies betrifft Kinder im Alter von 4-14 Jahren). Neben einem Überblick über die aktuellen niederländischen Standards diskutieren wir deren Eigenart und deren geschichtliche Entwicklung. Darüber hinaus betrachten wir mit Schulbüchern und Abschlussprüfungen weitere wichtige Einflussfaktoren auf die Unterrichtsgestaltung. Die Frage der unterrichteten Inhalte wird ergänzt um die Frage wie Mathematik konkret unterricht werden soll. Mit der „Realistic Mathematics Education“ bildet eine fachspezifische Bildungstheorie die Grundlage für den niederländischen Mathematikunterricht. Ein Blick auf ausgewählte Ergebnisse niederländischer Schülerinnen und Schüler bei nationalen und internationalen Leistungsuntersuchungen - und damit ein Blick auf den „outcome“ niederländischen Unterrichts - rundet das Bild vom niederländischen Mathematikunterricht ab. Dieser Artikel gibt nicht nur Informationen über die niederländischen Standards und Curricula, sondern auch einige kritische Reflexionen hierzu.

ZDM-Classification: B70, D10, D30

\section{Introduction}

Asking what mathematics teachers should teach their students is a question that on the one hand often rouses suspicion, while on the other hand great value is assigned to this question. The suspicion is especially raised by mathematics educators and researchers of mathematics. It comes from associating content questions with an approach of fragmentation of learning which is assumed to keep the students away from developing real understanding (e.g. Burton, 2002; Bereiter, 2002). Nevertheless, nowadays a broad audience, ranging from parents to business leaders and politicians, and from teachers to professional educators, deeply cares about what children learn in school (e.g. Senk \& Thompson, 2003). The content is even considered so important that the debate about it leads to heated discussions. In the United States this debate became known as the "Math War" (Becker \& Jacob, 1998).

The many controversies that emerge when talking about the "what," show that it is difficult to make wellfounded decisions about it. Some researchers, especially from the USA-e.g. Kilpatrick (2001) and Hiebert (1999) — even think that these decisions are necessarily based on beliefs about what is vital for students, and that therefore scientific educational research cannot answer this question.

In this paper we do not go into this discussion-this was done elsewhere (see Van den Heuvel-Panhuizen, 2005) —instead, we focus on the "what" of teaching in the meaning of the mathematical content that is taught. We will do this by giving an overview of the standards for mathematics education in the Netherlands which describe the intended content. The term "content" should be interpreted in a broad sense here. It also includes process goals such as the development of an investigative mathematical attitude and the ability of collaboration and communication.

The focus in this paper is on the standards for primary school and for the foundation phase of secondary school. To explain what these school levels mean in the Netherlands, we start in Section 2 with a short introduction to the Dutch school system. Because the standards for the primary and secondary school grades each have their own characteristics and history, we describe them in two parts. What both school levels have in common, however, is the way of teaching that forms the basis for the realization of the standards. Therefore, before describing the standards we give, in Section 3, a concise overview of the constituting principles of "Realistic Mathematics Education" (RME) - that is how the Dutch approach to teaching mathematics is called. In other words, before dealing with the "what" question we address the "how" question of mathematics education in the Netherlands. Consequently, Section 4 concentrates on the mathematics standards and curricula in primary school (K-grade 6). Section 5 describes what the students are taught in secondary school. The focus in this section is on the foundation phase of secondary school (grades 7 and 8). In Section 6 we change the perspective from input to output. This means that we look at student achievement and discuss the mathematical understanding that decisions about the "what" have resulted in. Finally, in Section 7, we round off the paper with some concluding remarks.

\section{The school system in the Netherlands}

The Dutch education system consists of primary, secondary and higher education (see fig. 1). Education is compulsory for children from age five until sixteen. However, most children in the Netherlands start their primary edu- 
cation right after their fourth birthday. Primary school includes kindergarten 1 and 2 (4-5 years of age), and the grades 1 through 6 (6-12 years of age). The Dutch name for these classes is "groep" (group). This means that primary school covers "groep 1" through "groep 8" (see the green part of fig. 1). There are about 7000 primary schools in the Netherlands.

After primary education children can go to three different types of secondary education: (1) VMBO is prevocational education preparing students for vocational education (MBO), (2) HAVO is general secondary education that prepares students for higher vocational education (HBO), and (3) VWO which is general secondary education that prepares students for university (WO). All the three types of secondary school begin with a foundation phase of two years. This phase is called "basic secondary education" (see the yellow part in fig. 1). In total there are about 700 schools for secondary education.

Alongside primary and secondary education there is also a strand for special education (SO).

Higher education in the Netherlands has a binary structure comprising universities (WO) and institutes for higher vocational education (HBO).

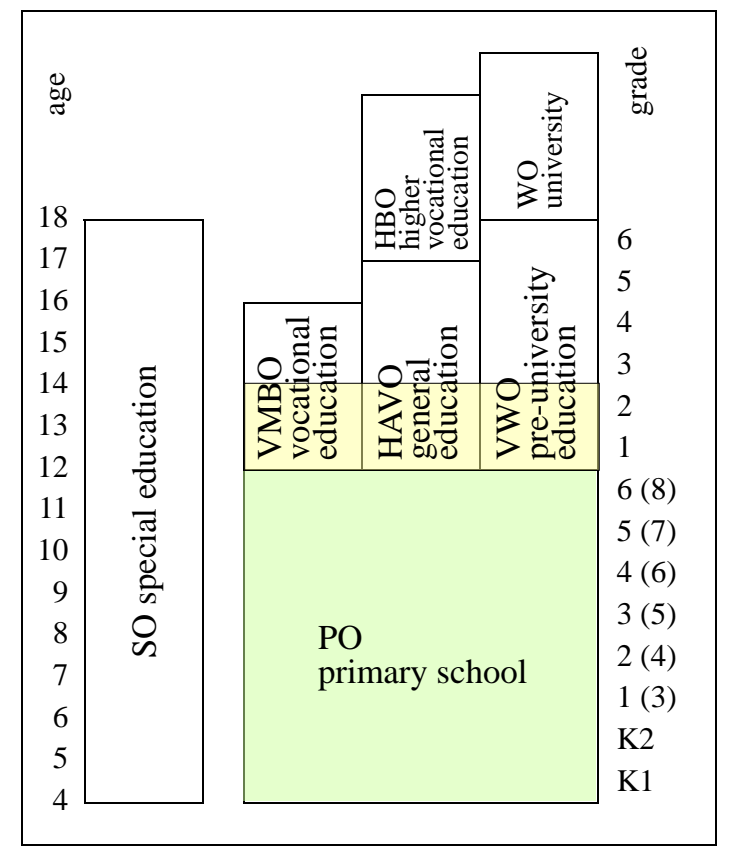

Fig. 1: Dutch school system

\section{The Dutch approach to mathematics education}

Although the focus in this paper is on the "what" of teaching, we cannot neglect the "how". Both go together. A choice for a particular content has consequences for the choice of a teaching method. For example, learning number facts needs a different kind of teaching activities than developing spatial reasoning skills. But the reverse is also true. The choice for a particular teaching method also determines what can be learned. For example, doing a worksheet full of number problems and thinking of number problems by oneself will lead to different learning results. Thus, in a way the content of learning can also be expressed by means of describing the learning environment the teacher has to offer. In other words, the "what" and the "how" of teaching are strongly related.

\subsection{History and basic philosophy of RME}

The development of what is now known as RME started around 1970. The foundations were laid by Freudenthal and his colleagues at the Institute for Development of Mathematics Education (IOWO), the oldest predecessor of the Freudenthal Institute (FI). The actual impulse for the reform movement was the inception, in 1968, of the Wiskobas project, initiated by Wijdeveld and Goffree. The project's first merit was that Dutch mathematics education was not affected by the New Math movement.

The present form of RME is strongly influenced by Freudenthal's (1977) view on mathematics. He felt mathematics must be connected to reality, stay close to children's experience and be relevant to society, in order to be of human value. Instead of seeing mathematics as ready-made knowledge to be transmitted, Freudenthal stressed the idea of mathematics as a human activity. Mathematics lessons should give students the "guided" opportunity to "re-invent" mathematics by doing it. This means that in mathematics education, the focal point should not be on mathematics as a closed system, but on the activity, on the process of mathematization (Freudenthal, 1968).

Later on, Treffers $(1978,1987)$ explicitly formulated the idea of two types of mathematization in an educational context; he distinguished "horizontal" and "vertical" mathematization. In broad terms, these two types can be understood as follows. In horizontal mathematization, the students come up with mathematical tools that can help to organize and solve a problem set in a real-life situation. Vertical mathematization is the process of reorganization within the mathematical system itself, for instance, finding shortcuts and discovering connections between concepts and strategies and then applying these discoveries. Thus horizontal mathematization involves going from the world of life into the world of symbols, while vertical mathematization means moving within the world of symbols (see also Freudenthal, 1991). Freudenthal stressed that these two forms of mathematization are of equal value. Furthermore, one must keep in mind that mathematization can occur at different levels of understanding.

Despite this clear statement about horizontal and vertical mathematization, RME became known as "real-world mathematics education.” This was especially true outside the Netherlands, but the same interpretation can also be found within the Netherlands. It must be acknowledged that the name "Realistic Mathematics Education" is somewhat confusing in this respect.

The reason, however, why the Dutch reform of mathematics education was called "realistic," was not just because of its connection with the real world, but was related to the emphasis that RME puts on offering the students problem situations which they can imagine. The Dutch translation of "to imagine” is “zich REALISEren.” It is this emphasis on making something real in your mind that gave RME its name. For the problems presented to the students this means that the context can be one from the real world, but this is not always necessary. The fantasy world of fairy tales and even the formal world of mathematics can provide suitable contexts for a problem, as long as they are real in the student's mind. 


\subsection{RME principles of teaching mathematics}

$\mathrm{RME}$ is a domain-specific instruction theory that is based on a view on mathematics as a subject, a view on how children learn mathematics and a view on how mathematics should be taught (Van den Heuvel-Panhuizen, 1996). These views can be characterized by the following six principles, each reflecting a specific characteristic of the identity of RME. ${ }^{1}$ Some of them originate more from the point of view of learning and some are more closely connected to the teaching perspective.

\subsubsection{Activity principle}

The idea of mathematization clearly refers to the concept of mathematics as an activity which, according to Freudenthal (1971, 1973), can best be learned by doing (see also Treffers, 1978, 1987). The students, instead of being receivers of ready-made mathematics, are treated as active participants in the educational process, in which they develop all sorts of mathematical tools and insights by themselves. According to Freudenthal (1973), using scientifically structured curricula, in which students are confronted with ready-made mathematics, is an "anti-didactic inversion." It is based on the false assumption that the results of mathematical thinking, placed in a subject-matter framework, can be transferred directly to the students.

The activity principle means that students are confronted with problem situations in which, for instance, they can produce fractions and gradually develop an algorithmic way of multiplication and division, based on an informal way of working. In relation to this principle, “own productions” play an important role in RME.

\subsubsection{Reality principle}

As in most approaches to mathematics education, RME aims at enabling students to apply mathematics. The overall goal of mathematics education is that students must learn to use their mathematical understanding and tools to solve problems. This implies that they must learn "mathematics so as to be useful” (see Freudenthal, 1968).

In RME, however, this reality principle is not only recognizable at the end of the learning process in the area of application; reality is also conceived as a source for learning mathematics. Just as mathematics arose from the mathematization of reality, so must learning mathematics also originate in mathematizing reality. Even in the early years of RME it was emphasized that if children learn mathematics in an isolated fashion, divorced from their experiences, it will quickly be forgotten and the children will not be able to apply it (Freudenthal, 1971, 1973, 1968). Rather than beginning with certain abstractions or definitions to be applied later, one must start with rich contexts demanding mathematical organization or, in other words, contexts that can be mathematized (Freudenthal, 1979, 1968). Thus, while working on context problems, the students can develop mathematical tools and understanding.

1 This list of principles is an adapted version of the five tenets of the framework for the RME instruction theory distinguished by Treffers (1987): "phenomenological exploration by means of contexts," "bridging by vertical instruments," "pupils' own constructions and productions," "interactive instruction," and "intertwining of learning strands."

\subsubsection{Level principle}

Learning mathematics means that students pass through various levels of understanding: from the ability to invent informal context-related solutions, to the creation of various levels of short cuts and schematizations, to the acquisition of insight into the underlying principles and the discernment of even broader relationships. The condition for arriving at the next level is the ability to reflect on the activities conducted. This reflection can be elicited by interaction.

Models serve as an important device for bridging this gap between informal, context-related mathematics and more formal mathematics. First, the students develop strategies closely connected to the context. Later on, certain aspects of the context situation can become more general, which means that the context acquires more and more the character of a model and as such can give support for solving other, but related, problems. Eventually, the models give the students access to more formal mathematical knowledge. In order to fulfill the bridging function between the informal and formal levels, models have to shift from a "model of" a particular situation to a "model for" all kinds of other, but equivalent, situations. ${ }^{2}$

The bus context (Van den Brink, 1989) is an example from daily life that can evolve to a more general and formal level. At first, an illustration is used to describe the changes at the bus stop. Later on, the bus context becomes a "model for" understanding all kinds of number sentences, and then the students can go far beyond the real bus context. They can even use the model for reasoning backward (Van den Heuvel-Panhuizen, 2003b).

An important requirement for having models functioning in this way is that they are rooted in concrete situations and that they are also flexible enough to be useful in higher levels of mathematical activities. This means that the models will provide the students with a foothold during the process of vertical mathematization, without obstructing the path back to the source.

The strength of the level principle is that it guides growth in mathematical understanding and that it gives the curriculum a longitudinal coherency. This long-term perspective is characteristic of RME. There is a strong focus on the relation between what has been learned earlier and what will be learned later. A powerful example of such a "longitudinal" model is the number line. It begins in first grade as (a) a beaded necklace on which the students can practice all kind of counting activities. In higher grades, this chain of beads successively becomes (b) an empty number line for supporting additions and subtractions, (c) a double number line for supporting problems on ratios, and (d) a fraction/percentage bar for supporting working with fractions and percentages.

\footnotetext{
2 It was Streefland who, in 1985, identified the shift in models as a crucial mechanism in the growth of understanding. Later on, this idea of a shift from the "model of" to the "model for" became a significant element within RME thinking about progress in students' understanding of mathematics (see e.g. Streefland, 1985a; Van den Heuvel-Panhuizen, 2003a).
} 


\subsubsection{Intertwinement principle}

It is also characteristic of RME that mathematics, as a school subject, is not split into distinctive learning strands. From a deeper mathematical perspective, the domains within mathematics cannot be separated. They are all linked to each other. Moreover, solving rich context problems often means that one has to apply a broad range of mathematical tools and understandings.

For instance, if children are shown a picture that shows an apartment building with a flag on top and they are asked to estimate the size of this flag, then they encounter various domains of mathematics such as estimation, measurement, ratio and geometry. In the same way, in the lower grades, mirror activities in which the children have to change the number of fiches visible in a mirror, clearly involve geometry and early arithmetic.

The strength of the intertwinement principle is that it brings coherency to the curriculum. This principle refers not only to the different domains of mathematics, but can also be found within them. In the number strand, for instance, topics like number sense, mental arithmetic, estimation and algorithms are closely related.

\subsubsection{Interaction principle}

Within RME, the learning of mathematics is considered to be a social activity. Education should offer students opportunities to share their strategies and inventions with each other. By listening to what others found out and discussing these findings, the students can get ideas for improving their strategies. Moreover, the interaction can evoke reflection, which enables the students to reach a higher level of understanding.

The significance of the interaction principle implies that whole-class teaching plays an important role in the RME approach to mathematics education. However, this does not mean that the whole class is proceeding collectively and that every student is following the same track and is reaching the same level of development at the same moment. On the contrary, within RME, children are considered as individuals, each following an individual learning path. This view on learning often results in pleas for splitting up classes into small groups of students, each following their own learning trajectories. In RME, however, there is a strong preference for keeping the class together as a unit of organization within which a variety of teaching methods can be applied; ranging from wholeclass teaching to group work to individual work. Moreover, within this structure of keeping the class together, differentiation is realized by providing the students with problems that can be solved on different levels of understanding.

\subsubsection{Guidance principle}

One of Freudenthal's (1991) key principles for mathematics education is that it should give students a "guided" opportunity to "re-invent" mathematics. This implies that in RME both the teachers and the educational programs have a pro-active role. They steer the learning process, but not in a fixed way by demonstrating what the students have to learn. Such an approach would be in conflict with the activity principle and would lead to pseudounderstanding. Instead, the students need room to con- struct mathematical insights and tools by themselves. In order to reach this, the teachers have to provide the students with a learning environment in which this construction process can emerge. One requirement for this is that teachers must be able to foresee where and how they can anticipate the students' understandings and skills that are just coming into view in the distance (see also Streefland, 1985b). Educational programs should contain scenarios that have the potential to work as a lever in shifting students' understanding. It is important for these scenarios that they always have the perspective of the long-term learning process, based on the goals the mathematics education is aimed at. Without this perspective, it is not possible to guide the students' learning. In other words, in this guidance principle the "how" and the "what" meet each other.

\subsection{The implementation of the RME principles}

As mentioned before, the above six principles express how the RME theory "thinks" about how children learn mathematics and how mathematics should be taught. Of course, this is not a fixed and univocal list of principles. Individual people involved with mathematics education in the Netherlands have different interpretations of what is meant by the RME theory. This is even true for staff members at the Freudenthal Institute. Nevertheless these principles articulate some communal ideas about learning and teaching mathematics of those who adhere to the RME theory. ${ }^{3}$

The principles can be found as the guiding tenets in all "sectors" of mathematics education: when developing curricula and standards, when writing textbooks, when designing tests, when educating future teachers, when counseling in-service teachers, when researching mathematics education, and - last but not least—when teaching children mathematics.

Notwithstanding the close relationship between the content of mathematics education and the teaching methods, the next sections clearly show that decisions about the "what" have been made in a broader context than the RME approach.

In the following, we describe the standards and curricula for the primary and secondary grades separately. The content decisions at both levels each have their own characteristics and history. Moreover, a division in two parts actually reflects the gap that exists in the Netherlands between teaching children of twelve years of age and younger, and teaching children older than twelve years.

\footnotetext{
${ }^{3}$ Although presently almost all the mathematics textbook series that are on the market have an RME approach, it does not mean that everybody in the Netherlands is happy with RME. Not all teachers agree with this approach. Especially some teachers in secondary education and some university professors think that RME does not satisfy the needs of high achievers. Concerning the group of low achievers a note of warning can be heard as well. Remedial educationalists often think that the RME approach is not helpful for this categoy of children. At the moment it is not clear what the proportions of this "opposition” to RME are. Our guess is that less than 5\% of all who are involved in mathematics education in primary and secondary education (including special education) has severe objections to RME.
} 


\section{Standards and curricula in primary school}

\subsection{Determinants of the primary school curriculum}

In Dutch primary schools there is no centralized decision making about the content that is taught. The schools are free to choose a mathematics textbook - they can even develop their own curriculum - and the textbooks can be published without approval by the Dutch government. Moreover, at the end of primary school there is no examination. Although there is a test and about $90 \%$ of the children take this test, this is, in fact, not a high-stake test. Actually, the teacher's advice at the end of primary school, rather than only the test score, in the end determines to what level of secondary education a child goes.

Despite this freedom in educational decision making-or probably we should say: thanks to the absence of centralized educational decision making - the mathematical topics taught in primary schools do not differ much between schools. In general, all schools follow roughly the same mathematics curriculum. This leads to the question: what factors determine this curriculum?

Apart from individual choices made by the teachers there are four determinants that influence what is taught in primary school mathematics education: (1) the mathematics textbooks series; (2) the "Proeve" books containing domain descriptions; (3) the core goals; and (4) the TAL learning-teaching trajectories.

Out of these four determinants, only the "core goals"-this is how the standards are called-have a legal status. They are approved and published by the Ministry of Education. ${ }^{4}$ In a way, the legal status means that there is a form of interference by government but - as will be clear later - these standards describe only globally the content to be taught. Thus, they cannot be seen as a form of central decision making of what is taught. Actually the most influential determinants for this are the textbooks. They are the most important tools for guiding the teachers' everyday decisions about what to teach. The textbooks, on the other hand, are mostly based on the "Proeve" books that describe for each subdomain of mathematics the key elements. The TAL learning-teaching trajectories form the newest tool to plot the pathway for teaching mathematics in Dutch primary schools.

In this paper we will concentrate on the standards, but before doing so we discuss in brief the other determinants.

\subsubsection{Textbooks}

In the current worldwide reform of mathematics education, speaking about textbooks often elicits a negative association. In fact, many reform movements are aimed at getting rid of textbooks. In the Netherlands, however, the contrary is the case. Here, the improvement of mathematics education was largely stimulated by the development of new textbooks that reflect the RME approach. If we restrict ourselves to the most prevailing textbook series, the schools can choose out of six different textbooks: "Pluspunt," "De wereld in getallen," Wis en Reken," "Rekenrijk," "Talrijk," and "Alles telt." The last one is based on the German textbook "Das Zahlenbuch.”

4 The official name is now "Ministry of Education, Culture and Science" (OCenW). Earlier it was named "Ministry of Education and Science" (MOW).
All the textbooks are published by commercial publishers who hire textbook authors; among them are often practicing teachers. The authors are independent developers of mathematics education, who are free to use ideas resulting from developmental research done at, for instance, the Freudenthal Institute (and its predecessors) and the SLO (Dutch Institute for Curriculum Development). Most authors also carry out investigations by themselves.

\subsection{2 "Proeve" books}

Another main determinant of the curriculum content is a series of books, called the "Proeve." These books contain descriptions of the various domains of primary school mathematics. Since the late eighties several of these books have been published ${ }^{5}$ of which Treffers is the main author. The complete title of the series is "Design of a national program for mathematics education in primary schools"6. Although the title of the series stresses that the books are meant as a "national program," it should be clear that there was no official interference by government to develop this program. Treffers and his colleagues wanted to label it as such in order to achieve a communal program. They have clearly succeeded in this aim. The "Proeve" books have been very influential on the development of textbook series, but, on the other hand, the textbook authors in their turn have also inspired the domain descriptions in the "Proeve."

\subsubsection{TAL learning-teaching trajectories}

The TAL learning-teaching trajectories are the newest determinants of what mathematics is taught in primary school. The development of these trajectories started in 1997 and were initiated and granted by the Dutch Ministry of Education. In a way these trajectories are a further elaboration of the core goals for primary school, which are considered to be insufficient to support improvements in the classroom or to control what children are taught (De Wit, 1997). The trajectories are meant to bring coherence into the primary school program, and provide a longitudinal overview of how children's mathematical understanding develops from kindergarten to grade 6 and how education can stimulate this process. The stepping stones the children will pass on their way to achieving the core goals form crucial elements in this overview. They can be seen as intermediate goals and can serve as benchmarks for assessment.

Until now three learning-teaching trajectories have been developed: one for calculation with whole numbers in the lower grades of the primary school (Treffers, Van den Heuvel-Panhuizen, \& Buys, 1999), one for the higher grades (Van den Heuvel-Panhuizen, Buys, \& Treffers, 2001) (both are also published in English; see Van den Heuvel-Panhuizen, 2001) and one for measurement and geometry in the lower grades of primary school (Van den Heuvel-Panhuizen \& Buys, 2004, 2005).

\footnotetext{
5 Treffers et al., 1989, 1990, 1994, 1996.

6 In Dutch the name is "Proeve van een Nationaal Programma voor het reken-wiskundeonderwijs op de basisschool.”
} 
The main purpose of these trajectories is to give teachers a hold for didactical decision-making. Although the trajectories contain many examples of classroom activities they are not meant as a practical recipe book, but as a framework at a conceptual level. The description of the learning pathway is based on fundamental elements of the mathematical content - that has much in common with Wittmann's (1999) “Grundideen” (fundamental ideas) in which the epistemological structure of the subject is expressed. Based on this description teachers can develop “a mental educational map” (Van den Heuvel-Panhuizen, 2005) that guides their teaching and with the help of which they can, if necessary, make adjustments to the textbooks.

In addition to helping teachers, a learning-teaching trajectory also affects the mathematics curriculum through giving support to textbook authors and giving inspectors a reference for controlling and supporting schools (Van der Wel et al., 2002).

\subsection{Core goals for mathematics in primary school}

The core goals provide the legal basis for what mathematics is taught in Dutch primary schools. These core goals describe in global terms the knowledge, insight and skills children should have achieved at the end of primary school. In this section we first discuss how these goals came into being and how they were changed during recent years.

\subsubsection{A short but eventful history}

Today it is difficult to imagine that there has been a time when government was hardly involved in defining the learning content in primary education. The first Dutch Education Act of 1801 only mentioned the three subjects to be taught in primary school: reading, writing and arithmetic. Later, in 1857, some subjects were added. One of them was "vormleer", a kind of visual geometry. About forty years later, in 1889, however, this subject was removed from the list of subjects and exchanged for "drawing” (see De Moor, 1999). This in-out pattern may look now as something from a past era when decisions about education were evidently not so well thought out. Later in this paper, however, we will show that this instability is still characteristic in today's decision making about mathematical content to be taught to students.

After 1889 we make a jump in time. The next education act that brought something new was the Education Act Primary School of 1985 . This act still only mentioned the subjects to be taught. New was that now "arithmetic" was changed into "arithmetic and mathematics."7

It took till 1993 before the core goals for the subjects in primary school were described and had passed through parliament (MOW, 1993a/b). Within the context of the so-called "freedom of education" that is highly valued in the Netherlands and part of our Constitution, this interference by government was not self-evident, and only accepted after a serious debate. However, the discussion was rather on the principle of having government interference than on the core goals themselves.

For mathematics the 1993 list consisted of five overall

\footnotetext{
${ }^{7}$ In this paper we use the name "mathematics."
}

goals and 23 specific core goals (see fig. 2a). In 1998, a revised version of the primary school core goals was launched (OCenW, 1998a), but the mathematics core goals were kept the same.

The 1993/1998 list was developed in close collaboration with the mathematics community, and was inspired by the first "Proeve" publication (Treffers et al. 1989). ${ }^{8}$ In fact, the core goals validated the main changes in the curriculum which had taken place since the reform movement that started in the beginning of the seventies. The predominant changes in the curriculum were:

- more attention was paid to mental arithmetic and estimation

- formal operations with fractions were no longer in the core curriculum; the students now only have to do operations with fractions in context situations

- geometry was officially included in the curriculum

- the insightful use of a calculator was incorporated in the curriculum.

The 1993/1998 list of core goals for primary school mathematics was also the starting point for the TAL project to work out the learning pathway to these core goals and determining intermediate attainment targets.

A new move in the history of core goals happened when the Ministry of Education, for political reasons, commissioned the Wijnen Committee to reduce the number of core goals and split up the list of core goals in a compulsory core part of $70 \%$ and an optional part of $30 \%$. The reduction was meant to lower the workload of schools and the optional part would give them more freedom in what mathematics they teach.

In this paper we do not have the possibility to discuss the recommendations of this committee in detail, therefore we confine ourselves with one example. A case in point is here what happened with geometry. After it was only officially in the curriculum since 1993 and its "realistic" elaboration had hardly begun, the Wijnen Committee came to the recommendation to remove it from the core curriculum. Even worse was that they changed the concept of geometry completely. What in the 1993/1998 version was a rich interpretation of geometry-including spatial reasoning and the understanding of three- and two-dimensional shapes and figures (see fig. 2a)became something that had no longer much to do with geometry, and actually reduced geometry to a kind of measurement. According to the Wijnen Committee, "the students [should] learn to carry out calculations with familiar two- and three-dimensional shapes" (Commissie Kerndoelen Basisonderwijs, 2002, p. 24). Apart from the fact that this core goal denies the essence of geometrylike many teachers, the Wijnen Committee seems not to know the difference between measurement and geometry-this goal description restricts geometry to skills which are precisely not within reach for part of the chil-

\footnotetext{
${ }^{8}$ Actually, this process to rethink the mathematics curriculum for primary school started in the early eighties with a report written by Treffers and De Moor (1984) and a survey (Cadot \& Vroegindeweij, 1986) that was carried out to investigate how the mathematics education community thought about the mathematics curriculum.
} 
dren. The most remarkable thing, however, was that this Wijnen Committee, commissioned by the Ministry of Education, in fact removed geometry from the primary school curriculum while at the same time the TAL team, funded by that same Ministry, was developing a learningteaching trajectory for geometry and the intermediate attainment targets for this domain.

Thanks to the strong reaction that the recommendation of the Wijnen Committee elicited from the Dutch mathematics education community, the Ministry asked a new committee to develop an alternative. This Klep Committee (Klep, 2002, p. 3) recommended the following for geometry: "The student learns to orient oneself in space, learns to describe geometric phenomena, learns to reason in two and three dimensions on the basis of their ability of spatial visualization and learns to solve simple geometric problems." This proposal awarded a place for geometry in primary school and brought about that the official core goal is now: "The students learn to solve simple geometry problems" (OCenW, 2004). Although, it is a very meager result, geometry is at least saved in the core goals.

What we can learn from this history is that from time to time the content is rearranged, that different parties operate at cross-purposes and that it is unclear on the basis of which decisions are made about the content.

\subsubsection{The mathematics that primary school students are supposed to learn according to the core goals}

Based on the recommendations of the Wijnen Committee and the alternative core goals proposed by the Klep Committee, the Ministry of Education published in 2004 the new list of core goals (see fig. 2b). This list was shorter than the 1993/1998 version. However, the Ministry did not follow the suggestion of the Wijnen Committee to have a compulsory core part of $70 \%$ and an optional part of $30 \%{ }^{9}$

Although we should focus now on the latest version of the core goals that was released in 2004, we think we can give a better picture of the mathematics Dutch primary students are supposed to learn if we present here the core goals of 1993/1998 and the 2004 version of the list.

Fig. $2 \mathrm{a}$ and fig. $2 \mathrm{~b}$ show what the core goals are in both lists. The first observation that can be made is that the latest version is remarkably shorter. The 23 core goals are reduced to 11 . This reduction is, among other things, the result of having the overall goals-that were in the 1993/1998 version included in the list of core goalsnow in a separate section that gives a short characterization of what the intended mathematics education is aimed at.

This characterization says that during primary school the students acquire familiarity with numbers, measures, shapes and patterns and the relationships and operations that belong to these topics. The focus is on learning to use mathematical language and developing mathematical literacy and numeracy. This mathematical language includes informal and formal notations, schematic representations, tables and graphs, and the language of the calculator. Mathematical literacy and numeracy includes a co-

9 The Klep Committee also protested against this 70-30 division. herent understanding of numbers, measures, and space, knowledge of reference numbers and measures, the ability to apply mathematics and carry out routine procedures in calculation, measurement and geometry. Both real-life contexts and mathematics contexts should be used to develop this understanding.

The characterization also emphasizes that education should take into account children's informal knowledge and that they should be offered the possibility to work on their own level in such a way that they develop a mathematical attitude and pleasure in doing mathematical activities. Finally, the characterization says that it is very important that students learn to explain their thinking to others and that they develop the ability to critique other students' strategies in a respectful way.

The characterization included in the 2004 version is very similar to the overall goals in the 1993/1998 list. In fact, both clearly reflect the principles of RME: the connection between mathematics and reality, applying mathematics in practical situations, and the focus on the students' own contribution in finding and describing their strategies.

A second observation that can be made is the "language" that is used in both goal descriptions. In the 1993/1998 version the goals describe the intended competences of students. The 2004 version describes opportunities to learn. The reason for this change in language has to do with making the list useful for a broad range of students. Formulating a list of competencies that is valid for all students means that only the very basic competencies can be included. The shift to opportunities to learn gives more possibilities to describe what is considered as important that students learn in mathematics education. Whether they actually will learn this in another thing that cannot be fixed by government.

A closer look at the content of the two core goal lists reveals that as far as the domain of number skills is concerned the difference between the two versions is not very large. For example, the 1993/1998 core goal "counting forward and backward with changing units" can be seen as included in the 2004 core goal that says "learn to understand in a general way the structure and relationships of whole numbers [...]." This latter goal also comprises the 1993/1998 core goal that says that the children should have "insight into the structure of whole numbers and the place-value system of decimals." Both lists of core goals also include addition and multiplication tables, written algorithms, estimation, and insightful use of a calculator. 


\begin{tabular}{|c|}
\hline CORE GOALS PRIMARY SCHOOL 1993/1998 \\
\hline Overall goals \\
\hline $\begin{array}{l}\text { Being able to make connections between mathematics and } \\
\text { their daily environment }\end{array}$ \\
\hline $\begin{array}{l}\text { Acquiring basic skills, understanding simple mathematical } \\
\text { language and applying it in practical situations }\end{array}$ \\
\hline $\begin{array}{l}\text { Reflecting on their mathematical activities and checking re- } \\
\text { sults }\end{array}$ \\
\hline $\begin{array}{l}\text { Searching for simple connections, rules, patterns and struc- } \\
\text { tures }\end{array}$ \\
\hline $\begin{array}{l}\text { Describing investigative and reasoning strategies in their own } \\
\text { words and using these strategies. }\end{array}$ \\
\hline Number skills $^{10}$ \\
\hline Can count forward and backward with changing units \\
\hline Can do addition tables and multiplication tables up to ten \\
\hline $\begin{array}{l}\text { Can do easy mental-arithmetic problems in a quick way with } \\
\text { insight in the operations }\end{array}$ \\
\hline $\begin{array}{l}\text { Can estimate by determining the answer globally, also with } \\
\text { fractions and decimals }\end{array}$ \\
\hline $\begin{array}{l}\text { Have insight into the structure of whole numbers and the } \\
\text { place-value system of decimals }\end{array}$ \\
\hline Can use the calculator with insight \\
\hline $\begin{array}{l}\text { Can convert simple problems which are not presented in a } \\
\text { mathematical way into a mathematical problem }\end{array}$ \\
\hline Written algorithms \\
\hline $\begin{array}{l}\text { Can apply the standard algorithms, or variations of these, to } \\
\text { the basic operations of addition, subtraction, multiplication } \\
\text { and division in simple context situations }\end{array}$ \\
\hline Ratio and percentage \\
\hline Can compare ratios and percentages \\
\hline Can do simple problems on ratio \\
\hline $\begin{array}{l}\text { Have an understanding of the concept percentage and can } \\
\text { carry out practical calculations with percentages presented in } \\
\text { simple context situations }\end{array}$ \\
\hline $\begin{array}{l}\text { Understand the relation between ratios, fractions, and deci- } \\
\text { mals }\end{array}$ \\
\hline Fractions \\
\hline $\begin{array}{l}\text { Know that fractions and decimals can stand for several mean- } \\
\text { ings }\end{array}$ \\
\hline $\begin{array}{l}\text { Can locate fractions and decimals on a number line and can con- } \\
\text { vert fractions into decimals; also with the help of a calculator }\end{array}$ \\
\hline $\begin{array}{l}\text { Can compare, add, subtract, divide, and multiply simple frac- } \\
\text { tions in simple context situations by means of models }\end{array}$ \\
\hline Measurement \\
\hline $\begin{array}{l}\text { Can read the time and calculate time intervals; also with the } \\
\text { help of a calendar }\end{array}$ \\
\hline $\begin{array}{l}\text { Can do calculations with money in daily-life context situa- } \\
\text { tions }\end{array}$ \\
\hline $\begin{array}{l}\text { Have an insight into the relation between the most important } \\
\text { quantities and corresponding units of measurement }\end{array}$ \\
\hline $\begin{array}{l}\text { Know the current units of measurement for length, area, vol- } \\
\text { ume, time, speed, weight, and temperature, and can apply } \\
\text { these in simple context situations }\end{array}$ \\
\hline $\begin{array}{l}\text { Can read simple tables and diagrams, and produce them based } \\
\text { on own investigations of simple context situations }\end{array}$ \\
\hline Geometry \\
\hline $\begin{array}{l}\text { Have mastered some basic concepts with which they can or- } \\
\text { ganize and describe a space in a geometrical way }\end{array}$ \\
\hline $\begin{array}{l}\text { Can reason geometrically using building blocks, ground } \\
\text { plans, maps, pictures, and data about positioning, direction, } \\
\text { distance, and scale }\end{array}$ \\
\hline $\begin{array}{l}\text { Can explain shadow images, can compound shapes, and can } \\
\text { devise and identify cut-outs of regular objects }\end{array}$ \\
\hline
\end{tabular}

Fig. 2a: CORE GOALS PRIMARY SCHOOL 1993/1998

\footnotetext{
${ }^{10}$ In the Dutch text the term "Vaardigheden" is used.
}

\begin{tabular}{|c|}
\hline CORE GOALS PRIMARY SCHOOL 2004 \\
\hline General mathematical insights and abilities \\
\hline Learn to use mathematical language \\
\hline $\begin{array}{l}\text { Learn to solve practical and formal mathematical problems } \\
\text { and express their reasonings in a clear way }\end{array}$ \\
\hline Learn to support and judge solution strategies \\
\hline Numbers and operations \\
\hline $\begin{array}{l}\text { Learn to understand in a general way the structure and rela- } \\
\text { tionships of whole numbers, decimal numbers, fractions, per- } \\
\text { centages and ratios and are able to calculate with them in prac- } \\
\text { tical situations }\end{array}$ \\
\hline $\begin{array}{l}\text { Learn to carry out mentally and quickly the basic operations } \\
\text { with whole numbers at least up to } 100 \text {; and know the additions } \\
\text { and subtractions up to } 20 \text { and the multiplication tables by heart }\end{array}$ \\
\hline Learn to estimate and calculate by approximation \\
\hline Learn to add, subtract, multiply and divide in a clever way \\
\hline $\begin{array}{l}\text { Learn written additions, subtraction, multiplications and divi- } \\
\text { sions in more or less curtailed standardized ways }\end{array}$ \\
\hline Learn to use the calculator with insight \\
\hline Measurement and geometry \\
\hline Learn to solve simple geometric problems \\
\hline $\begin{array}{l}\text { Learn to measure and to calculate with measurement units and } \\
\text { measures such as appear in time, money, perimeter, area, vol- } \\
\text { ume, weight, speed and temperature }\end{array}$ \\
\hline
\end{tabular}

Fig. 2b: CORE GOALS PRIMARY SCHOOL 2004

The big difference between the two lists appears when we look at the domains of ratio and percentage, fractions, measurement and geometry. The first two are included in the domain of numbers and operations; and measurement and geometry are reduced to one core goal each. Because of this reduction the list of 2004 is rather an enumeration of domains than a list of core goals. Actually, the list evokes memories of the situation of before 1993 when only the subjects were mentioned.

A consequence of this reduction is that the TAL learning-teaching trajectories and the included intermediate attainment targets, will play a large role in guiding decisions about mathematical content; the present list of core goals is again too global to give support for it. Also for the readers, the core goal lists are not informative on what is the intended mathematics curriculum in Dutch primary schools. Therefore, in the next section a short sketch is given of a part of the curriculum. The sketch is an elaboration of the core goals described in the section "Numbers and operations" (see fig. 2b) and is based on TAL.

\subsection{An elaboration of the core goals based on TAL}

The focus in this section is on whole number calculation because that is the only trajectory that is completed for primary school (see Section 4.1.3). Successively, we address here the domains of mental calculation, column calculation and algorithms, estimation, and using a calculator. To illustrate this we give examples of problems which students should be able to solve by the end of grade 6 .

\subsubsection{Mental calculation}

Mental calculation is the backbone of the primary school number strand. Mental calculation is considered as insightful calculation in which the children make use of memorized number facts and the properties of numbers and operations. Thus mental calculation is not simply doing calculations 
in the head. It is more a matter of using the head for making the calculations. Writing down intermediate steps or using the empty number line may be part of it. The basic strategies for mental calculation are: stringing, splitting and varying. In fig. 3 some examples are shown. These examples only contain bare problems, but the children should also be able to use these mental calculation strategies to solve context problems involving money, distances and other context related numbers.

\begin{tabular}{|l|l|}
\hline Problem & \\
\hline & Stringing strategy \\
\hline $325+243$ & $325+200=525 ; 525+40=565 ; 565+3=568$ \\
\hline $325-249$ & $325-200=125 ; 125-40=85 ; 85-9=76$ \\
\hline $6 \times 48$ & $3 \times 48=144 ; 3 \times 48=144 ; 144+144=288$ \\
\hline $78 \div 6$ & $10 \times 6=60 ; 3 \times 6=18 ; 10+3=13$ \\
\hline & Splitting strategy \\
\hline $325+243$ & $300+200=500 ; 25+43=68 ; 500+68=568$ \\
\hline $385-249$ & $300-200=100 ; 85-49=36 ; 100+36=136$ \\
\hline $6 \times 48$ & $6 \times 40=240 ; 6 \times 8=48 ; 240+48=288$ \\
\hline $78 \div 6$ & $60 \div 6=10 ; 18 \div 6=3 ; 10+3=13$ \\
\hline & Varying strategy \\
\hline $253+198$ & $253+200-2=451$ \\
\hline $19 \times 25$ & $(20 \times 25)-(1 \times 25)=475$ \\
\hline $124-78$ & $124-78=126-80=46$ \\
\hline $125 \times 7$ & $125 \times 7=7 \times 125=875$ \\
\hline $301-298$ & $298+\ldots=301 ; 3$ \\
\hline $16 \times 25$ & $16 \times 25=8 \times 50=400$ \\
\hline $75 \div 5$ & $5 \times \ldots=75 ; 15$ \\
\hline
\end{tabular}

Fig. 3: Mental calculation problems and strategies

\begin{tabular}{|c|c|}
\hline Column calculation & Algorithmic calculation \\
\hline $\begin{array}{l}463 \\
382+ \\
700 \\
140 \\
\frac{5}{845}\end{array}$ & $\begin{array}{l}1 \\
463 \\
\frac{382+}{845}\end{array}$ \\
\hline $\begin{array}{r}845 \\
382- \\
500 \\
-40 \\
5 \\
463\end{array}$ & $\begin{array}{l}714 \\
845 \\
382- \\
463\end{array}$ \\
\hline $\begin{array}{l}\begin{array}{r}163 \\
\frac{7 \times}{700} \\
420 \\
21 \\
1141\end{array} \\
\text { the same for } 70 \times 163 \\
\end{array}$ & 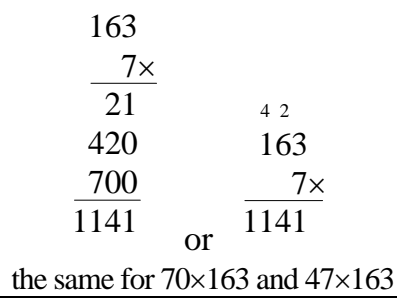 \\
\hline \begin{tabular}{l|l}
$\frac{422 \div 12=}{422}$ & 35 remainder 2 \\
$\frac{360-}{62}$ & $30 \times$ \\
$\frac{60-}{2}$ & $5 \times$
\end{tabular} & \\
\hline
\end{tabular}

Fig. 4: Two forms of written calculation

\subsubsection{Column calculation and algorithms}

By the end of primary school the students should be able to carry out multi-digit addition, subtraction and multiplication problems in the most abbreviated algorithmic form. The multiplication problems include only multiplying a multi-digit number by a single digit number. The traditional long division does not belong to the core goals for primary school anymore.

Column calculation is a more transparent way of written calculation and is an alternative for an algorithmic procedure. Column calculation actually lies between mental calculation and algorithmic calculation. In column calculation a decimal splitting strategy is applied. The calculation is carried out vertically but from left to right instead of from right to left. In column calculation one works with whole-number values and not with digits. The intermediate results are processed mentally. Fig. 4 shows some examples of both types of written calculation. Again the examples only contain bare problems, but the students should also be capable to apply these calculation forms when dealing with context problems.

\subsubsection{Estimation}

Although estimation problems can be found in every textbook, until recently there was not an elaborated teaching strand for this domain. Actually the TAL trajectory offers a first proposal for the pathway students can go to develop estimation skills. This pathway is based on a structure that has a subdivision into four subdomains: (1) exploring and rounding off numbers, (2) estimating in addition and subtraction problems, (3) estimating in multiplication and division problems, and (4) calculations with estimated values in problems where the necessary data are incomplete or unavailable.

In addition to these four subdomains, three learning phases have been distinguished: (1) the informal, (2) the rule-directed, and (3) the flexible and critical phase. In the informal phase the students can globally determine answers without using the standard rule for rounding off. In the rule-directed phase the students arrive at the standard rounding off rule for operating with numbers and learn to apply this rule. In the flexible and critical phase the students are capable of applying more balanced estimation methods when operating with numbers and they can deal in a critical way with rounded off and exact numbers.

Of the four basic operations, addition and subtraction are offered first in the estimation strand. Multiplication and division, however, are more difficult to perceive, because the deviations caused by the rounding off become magnified. Therefore the TAL trajectory advises to restrict the estimation in multiplication and division problems to rule-directed rounding off and to problems in which only one number has to be rounded off. Fig. 5 contains some examples of estimation problems. 


\begin{tabular}{|c|c|c|}
\hline \multicolumn{3}{|l|}{ Rounding off } \\
\hline \multicolumn{3}{|c|}{$\begin{array}{l}\text { > Indicate on a distance line where } 489 \mathrm{~km} \text { and } 7378 \mathrm{~km} \text { is } \\
\text { located. For each distance, choose the most suitable line. }\end{array}$} \\
\hline 0 & & $100 \mathrm{~km}$ \\
\hline 0 & & $1000 \mathrm{~km}$ \\
\hline 0 & & $10.000 \mathrm{~km}$ \\
\hline 0 & & $100.000 \mathrm{~km}$ \\
\hline \multicolumn{3}{|c|}{ Estimation in addition and subtraction } \\
\hline $\begin{array}{l}\text { Is the total number of visitors } \\
\text { more than quarter of a million? }\end{array}$ & $\begin{array}{l}\text { January } \\
\text { February } \\
\text { March } \\
\text { April }\end{array}$ & $\begin{array}{l}47,312 \\
13,561 \\
26,897 \\
107,348\end{array}$ \\
\hline \multicolumn{3}{|c|}{ > Approximately 1 billion - 1 million = Approximately ... } \\
\hline \multicolumn{3}{|c|}{ Estimation in multiplication and division } \\
\hline \multicolumn{3}{|c|}{$\begin{array}{l}\text { The wooden ornamental letters cost } 3.95 \text { Euro each. Arlette } \\
\text { buys seven letters to put on her bedroom door. Approxi- } \\
\text { mately how much does this cost? }\end{array}$} \\
\hline \multicolumn{3}{|c|}{$\begin{array}{l}\text { In total, } 4985 \text { Euro worth of lottery tickets were sold. } \\
\text { The lottery tickets cost } 5 \text { Euro each. } \\
\text { Approximately how many lottery tickets have been sold? }\end{array}$} \\
\hline \multicolumn{3}{|l|}{ Estimation with incomplete data } \\
\hline $\begin{array}{l}>\text { A traffic jam is } 5 \text { kilometers lon } \\
\text { there be in this traffic jam? }\end{array}$ & w man & s could \\
\hline
\end{tabular}

Fig. 5: Estimation problems

\subsubsection{Using a calculator}

In the TAL trajectory it is suggested to introduce the calculator as a calculation aid not earlier than grade 5 . If the calculator is used in lower grades then it should only be used as a didactical aid or a research object. Using the calculator as a didactical aid would mean that it is brought into action, for instance, to teach the students the underlying structures in the number system. An example of this is making use of the calculator to create multiples ("Press the + key, the 3 key and the = key repeatedly"). Using the calculator as a research object is when, for instance, two different types of calculators are compared ("What happens when you enter the problem $4 \times 5-4 \times 5$ ”).

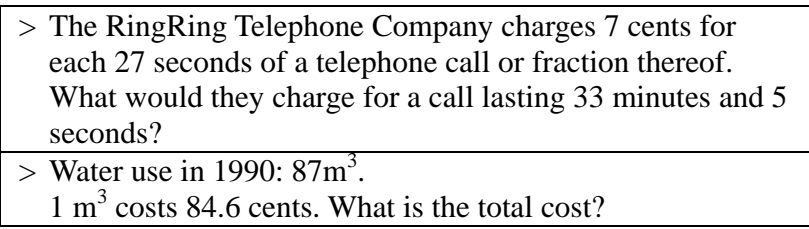

Fig. 6: Problems for which a calculator may be used

When it comes to using the calculator as a calculation aid, then the first thing is that the students should be able to make an adequate use of the calculator. Students should have insight in whether it makes sense to apply it or not (for instance, in the case of $1495 \div 5$ it does not make sense to use a calculator). Another thing is that using a calculator in problems such as shown in fig. 6 requires a good analysis of the problems and a clear view on how to organize the calculations.

Compared to the core goals, the TAL learning-teaching trajectory for calculation with whole numbers gives a better view of the content that is intended to be taught in primary education. It offers examples of number problems that students are supposed to be able to solve at the end of primary school and it also makes clear how the children can solve these problems and how the solution strategy can be seen as an indicator of the students' level of understanding (see also Van den Heuvel-Panhuizen \& Fosnot, 2001). In addition, the many examples of teaching activities that are included in the trajectory (not shown in this paper) give also a hold for making a decision about how to teach the selected content.

\section{Standards and curricula in the foundation phase of secondary school}

Although in this part of the paper the focus is on what is taught in the foundation phase of secondary school-the so-called "basic secondary education"-we give also some background information that concerns secondary education in general. To begin with, we discuss the main determinants of the mathematics curriculum in secondary school. Then it follows a general characterization of this curriculum and the curriculum changes that took place during the last decades. After that we zoom in on the present curriculum for mathematics in the foundation phase and the core goals formulated for basic secondary education.

\subsection{Determinants of the secondary school curriculum}

Like in primary school, in secondary school the textbooks have an important role in determining the content of day to day teaching. However, the factors that influence the content choices in the textbooks, differ from those in primary education.

At the first place the choices for what is taught in secondary school are mainly determined by the central final examinations at the end of secondary school.

Due to this determining effect of the examinations mathematics as a scientific discipline also has a certain but limited impact on the content that is taught. This influence is mainly visible in the curricula for preuniversity education (VWO), but sometimes it also detectable in lower levels of secondary education. The reason for this is the "streaming up" character of the Dutch school system which implies that students can change over from one school type to another. ${ }^{11}$ To make this streaming up possible, curricula should have content parts in common. A result of this requirement is a watereddown curriculum structure: the content for the HAVO curriculum was a watered down version of the one for VWO and the content for the pre-vocational level was a watered-down version of the HAVO content.

Finally, the revisions of the structure of secondary education have had their influence on what is taught to the

\footnotetext{
${ }^{11}$ Presently this possibility of "streaming up" is remarkably reduced.
} 
students in secondary school. In the past 25 years, the Dutch school system for secondary education underwent a number of changes and each change was accompanied by changes in the content of the curricula, including the mathematics curriculum.

Suggestions for what content was included in the mathematics curriculum came very often from staff members of the Freudenthal Institute (and its predecessors IOWO and OW\&OC). Through several curriculum innovation projects they were involved in the re-design of mathematics curricula for the different types and grade levels of secondary schooling. The main projects were: WISKIVON (1973-1980); HEWET (1978-1985); HAWEX (1987-1990); W12-16 (1987-1993); PROFI (1994-1996). The influence of these projects comes to the fore in Section 5.2. Next, we shortly describe the influence of textbooks and the examination programs.

\subsubsection{Textbooks}

Regarding the textbooks, the situation in secondary education is similar to that in primary education: mathematics education in the Netherlands is highly textbookdriven. Schools are free to choose a textbook series. Teachers can also make their own teaching materials, but that is not common practice.

Nowadays there are three main textbook series, all published by commercial publishers. These series are: "Moderne Wiskunde," "Getal en Ruimte" and "Netwerk." All of them more or less cover the same content and all reflect in some sense the principles of RME. The textbooks consist mainly of problems in context. They make use of informal language and informal strategies at the beginning of a new topic. Nevertheless, there are also differences between the textbook series. These differences are mainly visible in how the textbooks structure the learning sequence.

For example, the textbook series "Moderne Wiskunde" has a structure in the sequence of tasks, which is not always visible for students. A section starts with a problem to introduce the content topic that is addressed in the section. This problem is often presented in a meaningful real-life context. In the problems that follow, the topic of the section is further developed and practiced. Sometimes definitions or solution procedures are presented in separate textboxes.

The structure of the textbook series "Getal en Ruimte" is more explicit. This textbook most often uses an informal start as well. After that a rule or solution procedure is explained, followed by an example of how to apply it. Subsequently, the textbook offers a series of problems to practice. If we compare "Moderne Wiskunde" and "Getal en Ruimte" than we can say that there are only small differences between these two textbook series.

Textbooks not only provide the content to be taught, they also come with a variety of ready to use assessment materials, cd-roms with extra exercises and additional software. In other words, teachers do not need to worry, or even think about the content or other matters; the textbooks are "teacher-proof" and "guarantee" that particular content is delivered.

\subsubsection{Examination programs}

What content is included in the textbooks is largely determined by the content that is included in the final central examination at the end of secondary education. For the VMBO students the final examination is after four years of schooling, while the HAVO and VWO students have their final examination after respectively five and six years of schooling.

The content that is assessed in a final examination is described in a so-called "examination syllabus." These examination syllabi have been changed several times in the past decades. The changes involve their content and their nature. In former times the examination guidelines for mathematics consisted mainly of short lists of mathematical subjects. Nowadays these syllabi contain rather detailed lists of mathematics "standards" as well as a description of the more general goals to be addressed.

\subsection{Changes in secondary education during the last decades}

Since the 60s, several committees have discussed the modernization of the mathematics curriculum and examination programs in the Netherlands. In the next section we describe the major changes from that time in four time periods.

\subsubsection{The 60s}

A major change in secondary education in the Netherlands took place in 1968. The result of the socalled "mammoth law" was that the rather isolated school strands in secondary education were brought to more coherence. The same happened to the mathematics curriculum. From 1968 on, the mathematical content no longer consisted of separate courses for algebra, geometry, trigonometry and so forth, but it became one subject, with one textbook.

Responsible for this change was the Committee Modernization Mathematics Education (CMLW) installed in 1961 by the Ministry of Education. The CMLW also took care of the professionalization of (mainly older) math teachers to familiarize them with the new content. At first this was mainly content from "pure mathematics." Later there was also attention for applied mathematics like statistics and probability. Besides experiments in upper secondary schools, the CMLW experimented in lower secondary as well. The CMLW more and more evolved into a committee that not only advised on new curricula but also developed them themselves. Their curriculum development approach was an integrated one. It included research, experiments in school, and training of teachers.

While in this time period the New Math movement had a huge influence on the mathematics curricula in many countries, this movement did not have much impact in the Netherlands. Freudenthal prevented this. Due to his intervention the primary goal of the CMLW no longer was the introduction of modern new content, but the improvement of mathematics education (Wijdeveld et al., 2000). Nevertheless, there was some influence from the New Math movement. The textbooks included now and then set theory and, compared to the time before the New Math movement, more time was spent on formal notations. Freudenthal (1987) explained that he was not happy with this bit of New Math since it had no relation whatsoever 
with reality and did not reflect any insight in the "serving task" of mathematics.

In sum we can say that although one of the goals of the CMLW was to take notice of the applications of mathematics, this goal was not yet realized in the textbooks. However, a new development made this happen.

\subsubsection{The 70s and the beginning of the $80 \mathrm{~s}$}

At the beginning of the 70s the role of the CLMW was taken over by the Wiskivon group of IOWO. In 1974 a project was started to develop a new curriculum for the lower level of secondary education, which is now called VMBO. The Wiskivon group produced and experimented with exemplary teaching materials that were very different from the existing textbooks. The teaching materials were thematic units, in each of which contexts and problems interesting to students were presented that generated mathematical activities connected to the theme. Through reflection on the activities mathematical thinking was stimulated. Although it turned out to be very difficult to make a coherent curriculum based on these teaching materials and experiments, the ideas and materials from Wiskivon were little by little incorporated in the commercial textbooks. In addition to the work of Wiskivon, the changes in the curricula and examination programs for $\mathrm{VWO}^{12}$ and $\mathrm{HAVO}^{13}$ - the upper secondary school level-also influenced the textbooks for lower secondary education.

Both developments caused that in the textbooks for lower secondary education, the emphasis on structure and notation (a residue from the New Math movement) was gradually reduced in favor of more stress on contexts and applications.

\subsubsection{The mid 80 s to the mid 90s}

During this time a new structure in secondary education was prepared aimed at having the first two grades of all the school types offer a broad, general education for all students aged 12-14. The structure is called "basic secondary education." In 1993 this new structure was introduced. The new core curriculum that belongs to this new structure was compulsory and consisted of fifteen subjects. For each subject a set of core goals had to be established. It was appointed that this set will be redefined every five years. This has indeed been done. The first revision in 1998 resulted in some changes. In 2003 it was already decided that the basic education as a whole was to be redesigned. The existing core goals were not changed in that year.

For mathematics the introduction of the new structure of basic secondary education coincided with the renewal of the curriculum. The design of the new curriculum started in 1987. In that year the Ministry of Education installed the Committee for the Development of Mathematics Education (COW). The COW was commissioned to design this new mathematics curriculum, to describe

\footnotetext{
${ }^{12}$ Responsible for this new curricula and examination program was the HEWET project that was carried out at the Freudenthal Institute between 1978 and 1985.

${ }^{13}$ Responsible for this new curricula and examination program was the HAWEX project that was carried out at the Freudenthal Institute between 1987 and 1990.
}

the new core goals and to define a new examination program for VBO and MAVO, which are now called VMBO.

The examination program at that time reflected too much of a "tea-bag" model, in which the content of mathematics as a scientific discipline was watered down to make it feasible for students aged 12-16 in VBO and MAVO. This resulted in an often meaningless practicing of skills, especially in algebra (and calculus). The new examination program should be more in line with the changes effectuated in the examination programs and curricula for VWO and HAVO. More emphasis was needed on the use of contexts, on the meaningful use of mathematics. The examination program and the curricula that prepared for it should be better suited for the target group of students at VBO and MAVO. Most of them would go to vocational education.

The new curricula for lower secondary should prepare better for the new examination programs at all levels of secondary school. The development of these curricula was carried out within the W12-16 Project. ${ }^{14}$ The project consisted of staff members from the Freudenthal Institute and the SLO (National Institute for Curriculum Development). The project team worked closely together with teachers, teacher educators and commercial publishers.

Since the target group for whom the new curriculum was to be developed was very heterogeneous - containing four grade levels in several types of education-it was impossible for the project team to write new materials for all types of education and all grades. Instead the project team wrote exemplary student material, mainly for the new content areas. These materials were tried out in several schools. Besides these teaching materials the W12-16 group produced a number of other publications that described in detail the philosophy and content of the new curriculum.

Finally, the COW developed a list of core goals for mathematics in the basic secondary education. This list was more or less a by-product of the ideas and materials generated by W12-16. The core goals were published in 1993. We will come back to these core goals in Section 5.3.

\subsubsection{From 1993 till now}

After the introduction of the new structure of basic secondary education, the mathematics textbook series underwent many revisions. These revisions were based on the first years of experience with the new structure and the new approach to mathematics education. When teachers experienced problems concerning the content that was included in the textbooks, these problems were mostly "solved" in the next edition of the textbooks. ${ }^{15}$ Very soon it turned out that the new books were too easy

\footnotetext{
${ }^{14}$ W12-16 means "Mathematics for students aged 12-14."

${ }^{15}$ The many revisions show that textbook publishers were very flexible in carrying out revisions. However, we must take into account that changing textbooks for the basic secondary education is easier than changing textbooks for the other years. Note that the first formal assessment - the final examination - takes place only after four years in VMBO. Therefore, in the first two years of secondary school more freedom seems to exist for changes in the textbooks. The only formal criterion is that core goals must be addressed in the mathematics lessons.
} 
for the students in the first years of HAVO and VWO. One of the ideas behind the new curriculum was to postpone the formal approach to algebra, especially the use of variables and the algebraic skills, in favor of a more intuitive, broad and applied approach in the first two years. However, when the students entered upper secondary education, teachers complained about the lack of algebraic skills.

Another factor that influenced the new editions of the textbooks was the growing impact of IT (information technology) on education. While on the one hand IT only slowly found its way into the classrooms, on the other hand the possibilities seemed promising and schools more and more invested in the hardware. Although in 1993, there was already a number of dedicated software programs for mathematics education available, the increase in access to the internet largely stimulated the development and use of small interactive computer programs. From the mid 90s on the FI developed so called "applets" that were connected to the mathematics curricula for both primary and secondary education. The teachers could get access to these applets through special FI websites. Textbook publishers started to include these applets into their textbooks from the late 90s and as a result the so-called "mixed-media editions" came into being around 2000. However, this new development may not have changed the content of the curriculum so much, but rather the way of teaching and the didactical approach.

At the end of the 90s the concept of basic secondary education became more and more subject to critique. The 1999 evaluation report of the Inspection of Education made a number of shortcomings visible (Inspectie van het onderwijs, 1999). There were too many subjects (fifteen), which caused an overloaded program for the students. Other shortcomings were that connections between the subjects were missing and that the content was too much designed top-down by content experts. The curriculum design for basic secondary education targeted at the non-existing average student. A last point was that the schools felt that they did not have enough freedom to adjust their instruction to the needs of their student population.

Therefore, in 2002 the Ministry of Education, based on an advise of the Education Council of the Netherlands (Onderwijsraad, 2001), installed the Task Force "Renewal Basic Secondary education" for the renewal of the basic secondary education. This task group had as one of its main tasks to advise on the revision of the core goals and the subjects. The group had to select, update and (re)group core goals in order to come to a more coherent and reduced set of core goals and subjects. The set of core goals would have to be attainable in two thirds of the first two years of secondary school. This enterprise resulted in an integral advise on the renewal of the basic secondary education published in 2004 (Taakgroep Vernieuwing Onderbouw, 2004a). This advise contains a new list of 58 core goals, of which 9 are about mathematics. These core goals must be implemented in 2006.

\subsection{Core goals for mathematics in the foundation phase of secondary school}

In 1993 the new mathematics curriculum for basic secondary education was described in four content areas: (1) number, measurement and estimation, (2) algebraic relationships, (3) geometry, and (4) information processing and statistics.

In the algebra strand the old stress on linear and quadratic functions was replaced by a new approach to relations. Besides formulas, now graphs, tables and text became important representations of algebraic relations. There was much emphasis on algebra related to meaningful situations. Different types of functions, like linear, exponential, periodical, were explored at the same time in the early grades of secondary school, in an informal, context-related way.

In the geometry strand, both the vision geometry and the relationship between two-dimensional and three-dimensional shapes were new topics in lower secondary education. These topics were introduced to better prepare students for the geometry of space in upper secondary education, and at the same time to connect better to what was done on geometry in primary school.

The introduction of a number strand in the secondary school curriculum meant an acknowledgement of the fact that in primary school the learning of arithmetic is not yet finished. Especially in the subdomain of rational number (fractions, decimals, ratios and percentages) a lot of the students are not proficient when they leave primary school. The core goals in this strand secure a better connection between mathematics in primary and in secondary education. Finally in the information processing and statistics strand a first exploration of graph theory, matrices and descriptive statistics became new content for lower secondary mathematics. Probability was a much discussed topic in the W12-16 project: the outcome of these discussions was that probability theory was not formally addressed in the core goals of basic secondary education. There was only one core goal referring to this domain in a very informal way, namely: "Use models to make judgments regarding possible future events and developments in simple, practical situations” (see fig. 7a).

The mathematical content for basic secondary education was described in the 29 core goals listed in fig. $7 a^{16 .}$ These core goals give a rather detailed description of the mathematics to be taught, but they do not specify the level at which these must be taught. The Dutch Ministry of Education, Culture and Science states (OCenW, 1998b, p.7-8): "Attainment targets describe the standards that students are expected to attain in terms of knowledge, understanding and skills. The requirement for schools is that they use the attainment targets as the minimum levels of achievement for the completion of basic secondary education. [...] Within the boundaries it sets for itself, and those of the type of school to which it belongs, each school is free to define the achievement levels for its students. The assumption is that a teacher will 'place the bar as high as possible,' depending on the potential and interests of the student.”

\footnotetext{
${ }^{16}$ The list in fig. 7a contains the core goals after the revision in 1998.
} 


\section{CORE GOALS BASIC SECONDARY EDUCATION 1998}

\section{Arithmetic, measurement and estimation}

Solve problems whose resolution involves choosing between mental arithmetic, the use of a pocket calculator, written calculation. Recognize what needs to be done to solve the problem and should be able to perform the relevant calculations correctly.

Use a pocket calculator properly; more particularly, they should be able to convert fractions, percentages, roots and powers into finite decimals.

Estimate the result of a calculation or measurement using reference data and to check a result to determine whether it is in a plausible range.

Work with common units of length, area, volume, time, angle and monetary value and to perform calculations expressed in these units.

Perform calculations that involve ratios and scales.

Organize, add and subtract negative numbers that relate to meaningful situations.

Understand how ratios, fractions and decimals relate to one another and should be able to perform simple calculations involving ratios, fractions and decimals, by making use of mathematical models.

\section{Algebraic relationships}

Describe a simple relation between two real variables using an expression, a table, a graph or a (verbal) formula, or deduce such a relation from a description in any of these forms.

Describe changes in the relation between two real quantities, using the four descriptive forms referred to above.

Convert a description in one of the four forms referred to above into a description in one of the other forms.

Read, compare and interpret relations and to utilize them in the resolution of actual problems by using expressions, tables, graphs and (verbal) formulae.

Recognize and interpret the characteristic properties of simple relations, such as maximum and minimum values and the values of a given quantity which are relevant in the particular context. Determine, express and project regularity in numeric patterns and tables.

By reference to a given graph, possibly at a given interval, determine whether a constant, rising, falling or periodic relation exists.

By reference to specific points in a graph and to its line and shape, draw conclusions regarding the situation depicted. Substitute figures for variables in a (verbal)formula and to calculate the value of a remaining variable.

Determine or approximate whether simple relations give similar results and to determine the intervals within which one relation is greater than another.

Use simple computer programmes to solve problems involving relations between two quantities.

\section{Geometry}

Interpret two-dimensional representations of three-dimensional entities and to describe them, to visualize them in three dimensions and to depict them to scale and more approximately, either on paper or on screen. The representations in question are: photographs; pattern drawings; plans; maps; construction ikeafringspractical tasks with tangible objects and by reference to representations of three-dimensional figures. Produce elevation drawings, full-size drawings, patterns and the like and make scale drawings of the planes of three-dimensional figures. Estimate, measure and calculate the angles, dimensions, areas and volumes of two and three-dimensional objects.

When drawing and calculating angles and dimensions and when reasoning, demonstrate familiarity with the properties of angles and with geometric terms such as "parallel,"

"perpendicular" and "direction."
Describe regularity in and the properties of geometric patterns and objects, and use knowledge of these matters when making calculations and when extending and modifying such patterns and objects.

Use instruments when drawing, making calculations, performing practical tasks and reasoning. The instruments in question are: ruler, protractor, setsquare, compass, instruments made by the pupils themselves and the computer.

\section{Information processing and statistics}

Make use of graphs and other visualizations of information when solving practical problems and determine whether a given visualization presents the information in an appropriate manner. Read and interpret statistical representations. Process and modify such data, in the form of a table, graph or diagram, as well as characterize it using centre indicators.

Systematically gather, describe and organize data for statistical study purposes.

Use computer programmes for the statistical processing of data, as well as to interpret the associated output.

Use models to make judgements regarding possible future

events and developments in simple, practical situations.

\section{Fig. 7a: CORE GOALS BASIC SECONDARY EDUCATION 1998}

\section{CORE GOALS BASIC SECONDARY EDUCATION 2004}

Learn to use appropriate mathematical language to order their own thinking and to explain to others, learn to understand the mathematical language used by others.

Learn to recognize and use mathematics to solve problems in practical situations while working alone or with others.

Learn to set up mathematical argumentation, and to discern mathematical argumentation from opinions and statements and learn to give and receive mathematical critique with respect for each other's way of thinking.

Learn to understand the structure and relationships of positive and negative numbers, decimals, fractions, percents and ratios and learn to work with these is meaningful and practical situations.

Learn to calculate in an exact way as well as by approximation, and to reason based on insight in the precision, the order of magnitude and the error margins fitting a given situation. Learn to measure, learn to understand the structure and relationships of the metric system and learn to calculate with measurement units for quantities that are common in relevant applications.

Learn to use informal notations, schematic representations, tables, graphs and formulas to understand relationships between quantities and variables.

Learn to use two-dimensional (flat) and three-dimensional (spatial) shapes and structures, learn to make and interpret representations of these, and learn to calculate and reason using their properties and measurements.

Learn to systematically describe, order and visualize data and to critically judge data representations and conclusions.

\section{Fig. 7b: CORE GOALS BASIC SECONDARY EDUCATION} 2004

In addition to the 29 core goals for mathematics five general objectives for mathematics education are described. These are objectives such as: developing a mathematical attitude, acquiring proficiency in the use of mathematical language, gaining insight into the applications of mathematics in other disciplines. Furthermore an overview is given of how mathematics education contributes to the attainment of the general educational targets.

Although the list of core goals is described in four sepa- 
rate content areas the characterization of the intended curriculum makes clear that it is focused on making connections between these strands while teaching. To stimulate this coherence a special fifth "strand" was initially included in the publications of the W12-16 project, the socalled "integrated mathematical activities." The description of this strand gave concrete examples of how the intertwinement of strands could be realized. In the formal publication of the core goals this strand is not included.

Although the core goals were not developed to describe a didactical approach, they clearly reflect the principles of RME:

- mathematics should be useful and meaningful

- meaning comes before formalization

- it is important that students pass through various levels of understanding, from informal and concrete to more formal and abstract

- the teacher guides the students in this process.

The new list of core goals that is published in 2004 (see fig. 7b) is much shorter than the 1998 list. The new list contains only nine core goals for Mathematics, which are formulated in more general terms than the old ones.

The reason for this reduction and the more general formulation is that this gives schools more freedom to define the content in detail and to plan instruction time as they see fit for their student population. This fits the overall goals of the renewal of the basic secondary education: more freedom for schools, and possibilities for tailor-made solutions. The core goals now only cover two thirds of the program. The differential part that covers the other third, is not meant to be fully filled at liberty by the schools. In general this part has to fulfil three functions: meeting the requirements of the different school types; realising "tailor-made" solutions (remedial teaching, supplementary materials); characterizing the school.

In addition to the list of core goals, the Task Force "Renewal Basic Secondary Education" also produced a general characteristic of mathematics education. In this characteristic, emphasis is put on the fact that students need mathematics in several ways in several different situations as well in as outside of school. Therefore students should develop insights and skills in areas of number, quantity, measurement, shapes, structures and relationships, operations and functions. Moreover, the students continue in developing their mathematical language, literacy and numeracy. What this all means is put in almost the same words as in the primary school core goals and characteristic.

The characteristic that is given for secondary education (Taakgroep Vernieuwing Onderbouw, 2004b, p.18) also says that "[in] basic secondary education a large number of students will be challenged to mathematical activity if this can be done in a meaningful context fitting their level. Others may be more challenged by a more abstract and theoretical approach. Both should be done in a broad field of applications." Moreover, attention should be paid to the connections with other subjects. It is explicitly stated that this connection is a two-way issue: context from other subjects can be used in mathematics education and aspects of mathematics can get attention in other subjects.
In sum we can say that this characteristic clearly fits to the principles of RME.

However, a closer look at the two lists of core goals shows some interesting differences between the 1998 list and the list from 2004.

The first three core goals in the 2004 list are rather general. They deal with mathematical language, attitude and argumentation. These issues seem to be missing in the 1998 list, but this is not in fact the case. In the 1998 version these issues were included in the general goals.

A clearer difference between the two lists is that the 1998 list is far more detailed. For example, the 1998 list had eleven core goals for algebra while in the 2004 list algebra is described in the core goal about learning to use relationships between quantities and variables, and in the first core goal on developing a mathematical language.

The remarkable thing about the new core goals is that, since they are more general than the old ones, nothing needs to be changed in the textbooks. At the same time it is most likely that the central final examinations will still determine strongly what content will be taught. Nevertheless, these core goals give innovative schools and teachers the freedom to develop a new approach to mathematics education tailored to the abilities and needs of their own students.

It is still too early to tell what schools and teachers will do to renew the first two years of Secondary Education at their own schools. The larger freedom for schools to make their own choices and design their own education fits the general policy of the government to decentralize and give more responsibilities to schools. The Task Force Renewal Basic Secondary Education consulted school managers and teachers and found that the majority was in favour of a change.

For mathematics nowadays teachers hardly use or even know the core goals. They rely on their textbooks to address them. In the new situation with the less detailed goals we can assume that the more traditional teachers will keep relying on their new textbooks. Innovative schools that want to change their education into more competency-based education, have difficulty deciding how to deal with mathematics. They have questions as to how to address mathematics in a thematic approach; how to connect mathematics to other subjects; what mathematics should be taught as a separate subject etcetera. Also commercial publishers struggle with these questions. The greater freedom will allow for more differences between schools, and this can apply to the way they teach mathematics as well as to the specific detailed content of the math.

\section{Achievement scores of Dutch students}

In this section we change the perspective from input to output. This means that we look at student achievement and discuss the mathematical understanding that decisions about the "what" have resulted in. In other words, do the students learn what education is supposed to teach them? For primary school we restrict ourselves to some results from grade 6, and for the foundation phase of secondary school we discuss some test scores from grade 8 . 


\subsection{Some results from primary school}

What level of mathematical knowledge have Dutch students achieved after eight years of schooling (included two years of kindergarten)?

\begin{tabular}{|c|c|c|c|c|c|}
\hline & \multicolumn{5}{|c|}{ Achievement level } \\
\hline & $\mathrm{E}$ & $\mathrm{D}$ & $\mathrm{C}$ & $\mathrm{B}$ & $\mathrm{A}$ \\
\hline \multicolumn{6}{|l|}{ Mental calculation } \\
\hline \multirow{4}{*}{$\begin{array}{l}>12 \text { cans of coffee can be } \\
\text { filled from a big container } \\
\text { full of coffee. Each can con- } \\
\text { tains } 8 \text { cups of coffee. How } \\
\text { many cups of coffee can be } \\
\text { poured out the big container } \\
\text { in total? } \\
>8 \times 17= \\
>256 \div 8= \\
>1743-997=\end{array}$} & & & & & \\
\hline & & & & & \\
\hline & & & & & \\
\hline & & & & & \\
\hline \multicolumn{6}{|l|}{ Column calculation / algorithms } \\
\hline \multirow{2}{*}{$\begin{array}{l}\text { > In a soccer stadium } 100000 \\
\text { people can be placed. There } \\
\text { are only } 78853 \text { people in the } \\
\text { stadium. How many more } \\
\text { people can enter? } \\
>\text { The Klabbers family is going } \\
\text { for a car treasure hunt. The } \\
\text { tour is } 195 \mathrm{~km} \text {. When they } \\
\text { start the odometer says: } \\
025789 \\
\text { In the end the odometer says: } \\
\text { 026009 } \\
\text { How long was their detour? } \\
\text { km }\end{array}$} & & & & & \\
\hline & & & & & \\
\hline \multicolumn{6}{|l|}{$>806 \div 26=$} \\
\hline \multicolumn{6}{|l|}{$>236 \times 405=$} \\
\hline \multicolumn{6}{|l|}{ Estimation } \\
\hline $\begin{array}{l}\text { 17000-2997-2999-2996= } \\
\text { First round off the numbers } \\
\text { that you subtract. } \\
\text { The result of this subtraction } \\
\text { is a bit more than ... }\end{array}$ & & & & & \\
\hline \multicolumn{6}{|l|}{ Using a calculator } \\
\hline \multirow{2}{*}{$\begin{array}{l}\text { } 2475 \text { supporters have to be } \\
\text { bussed to a match. In one bus } \\
48 \text { supporters can be placed. } \\
\text { How many busses are } \\
\text { needed? } \\
>\text { Water use in } 1990: 87 \mathrm{~m}^{3} \text {. } \\
1 \mathrm{~m}^{3} \text { costs } 84.6 \text { cents. } \\
\text { What are the total costs? }\end{array}$} & & & & & \\
\hline & & & & & \\
\hline \multirow{4}{*}{$\begin{array}{l}\mathrm{E}=.10 \text { percentile students } \\
\mathrm{D}=.25 \text { percentile students } \\
\mathrm{C}=.50 \text { percentile students } \\
\mathrm{B}=.75 \text { percentile students } \\
\mathrm{A}=.90 \text { percentile students }\end{array}$} & & \multirow{4}{*}{\multicolumn{4}{|c|}{$\begin{array}{l}\text { insufficient mastery } \\
\text { ( }<50 \% \text { chance correct) } \\
\text { average mastery } \\
\text { ( } 50-80 \% \text { chance correct) } \\
\text { good mastery } \\
\text { ( }>80 \% \text { chance correct) }\end{array}$}} \\
\hline & & & & & \\
\hline & & & & & \\
\hline & & & & & \\
\hline
\end{tabular}

Fig. 8: Student achievements from grade 6

To answer this question we will use the results from the latest available PPON study ${ }^{17}$ (Janssen et al., 1999).

${ }^{17}$ PPON Study is carried out every five years by CITO, the Dutch National Institute for Educational Measurement, to
Of course we cannot give a full description of the results in this paper. We focus on the content domain of number of which we gave a picture in Section 4.3.

Fig. 8 shows for four ability categories of students (achievement level A-E) whether they are able to solve particular number problems or not. First of all, it is difficult to make conclusions on these data. It is not simple to say whether the students reached the core goals or not and whether the results differed for the different subdomains. It looks as if the subdomain "column calculation and algorithms" was most accessible for the weaker students. In one of these problems even the $10 \%$ weakest students reached an average mastery. ${ }^{18}$ More difficult were estimation problems and problems in which the students had to use the calculator.

Another thing that fig. 8 reveals is that there are several problems for which even the $25 \%$ best students have only an average or an insufficient mastery. This is, for instance, the case for mentally calculating 1743-997 and finding, by written calculation, the number of kilometers of the detour that was made by the Klabbers family. Also remarkable is that even the $10 \%$ best students could not find the water costs by using a calculator.

This feedback from Cito about the mathematical knowledge and understanding students have reached at the end of primary school is a very important source for the refinement of our standards and curricula and adjusting teaching methods. However, the effects of this feedback are not that transparent. We think that the PPON results are certainly used by researchers and developers (including textbook authors and test designers) as a reference for developing new materials for mathematics education and adjusting teaching methods, but it very hard to trace the influence of the PPON results. So far we know, no research has been carried out into the effects of publishing the outcomes of education.

\subsection{Some results from foundation phase of secondary school} What level of mathematical knowledge have Dutch students achieved after ten years of schooling (from kindergarten through the second grade in secondary school)?

\subsubsection{No compulsory central assessment}

The students' mathematical level at the end of foundation phase of secondary education is not easy to determine. The reason for this is that there is no formal assessment at the end of this phase anymore. This was different when the basic education was formally introduced in 1993. Then, schools were obliged to have their students take a test. The test was centrally designed under responsibility of the government. However, in school year 1994/1995 which was the first time that the assessment was used, there were huge problems. The test was the same for students in all types of schooling and did not take into account the differences between the students levels. Furthermore the test was too long and the organization (school had to make copies for all students) was tedious and time-consuming. In 1996 changes were proposed in

monitor the outcome of education in primary school. The study collects data from grades 3 and 6 .

${ }^{18}$ In fig. 8 is explained what this means. 
the way of assessing students. The tests were now designed at two levels and covered only a small part of the core goals. Despite these changes the problems persisted. Therefore in 2001 the ministry decided to cancel the compulsory assessment.

Now that the foundation phase is being redesigned the discussion on how to assess students at the end of the first two years of secondary school is a burning issue again. It is clear however that there will not come a compulsory central assessment.

\subsubsection{Some indications from an international study}

Some indications of the level of students achievement on mathematics at the end of the foundation phase of secondary school can be found in the scores of the eight-graders in the international and national reports about the TIMSS 2003 Study (Mullis et al., 2004; Meelissen et al., 2004).

First of all, in the international ranking of the mathematics scores of the 46 countries, the Dutch eightgraders are rather at the top. The Netherlands is the 7th best country; $75 \%$ of the Dutch students score above the international total average. ${ }^{19}$

If we look at how the Dutch score on mathematics is composed then it turns out that Dutch students have a higher average score on data handling and measurementthis means that these average scores lay above the total national average score-and a low average score on algebra and geometry. The average score on number lays a bit above the average of the total national score (see fig. 8). The zero on the scale to the left of this graph indicates the Dutch average of mathematics content area scale scores (536) set to zero. The other numbers indicate the differences. For example for Data the Dutch score is 560, which is the same as a difference of +24 .

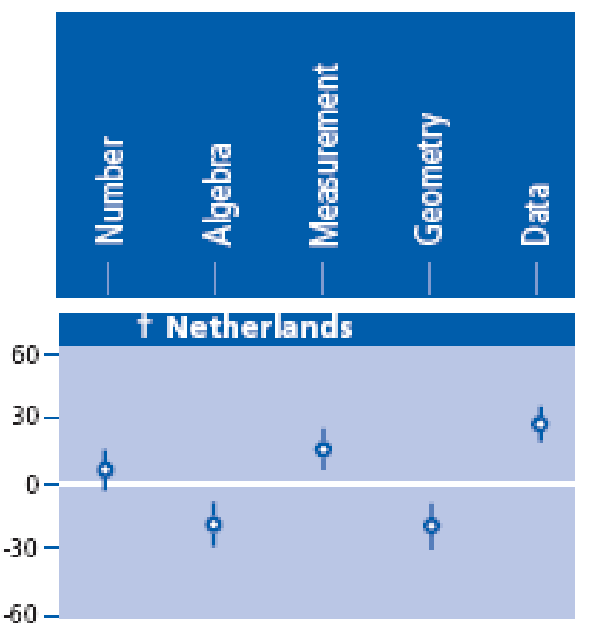

Fig. 9: Differences from the Dutch own Average of Mathematics Content Area Scale Scores (Mullis et al., 2004, p.111)

These profiles are made for every country. They reveal that many countries performed relatively better or worse in several content areas than they did overall. The profiles also reveal more variation across the content areas in

\footnotetext{
${ }^{19}$ Mentioning these TIMSS results of the Dutch students does not mean that we think that the high ranking of the Dutch students guarantees that they have achieved a high level of understanding mathematics.
}

some countries than in others. There is no general pattern between countries.

Internationally at the eighth grade, the differences in average achievement between the highest and lowestperforming countries were greatest for geometry and measurement (351 and 349 scale-score points, respectively), next for number (344), then algebra (322), and least for data (286) (Mullis et al., 2004, p.108).

On the 25 number trend items ${ }^{20}$ included in TIMSS 1999 and in TIMSS 2003, the Dutch students on average scored $60 \%$ correctly while the international average was $50 \%$. For the 16 trend items in algebra these scores are respectively $51 \%$ and $45 \%$; for the 16 measurement trend items 58\% and 41\%; for the 12 geometry trend items 57\% and 50\%; and for the 10 data trend items $79 \%$ and $62 \%$. Overall on the 79 trend items, the Dutch students scored $60 \%$ correctly, while the international average was $48 \%$.

Of course, it is impossible to report here in detail about the TIMSS findings. We can only discuss some results exemplarily and therefore we restrict ourselves to two examples from the number strand and one algebra problem. The problems we have chosen are so-called "Benchmark problems." Teachers, mathematics educators, textbook authors and researchers can take these problems as a reference for their work. Based on the TIMSS results the problems are categorized in different difficulty levels.

The problem in which the students have to find the closest number to 10 (see fig. 10) belongs to the low international benchmark of mathematics achievement.

Which of these numbers is closest to 10 ?
(A) 0.10
C 9.99
C 10.10
(D) 10.90

Fig. 10: Find the closest number to 10 (from Mullis et al., 2004, p. 84)

According to the TIMSS report, problems within this category "provide some evidence that students can do basic computations with whole numbers without a calculator. They can select the two-place decimal closest to a whole number” (Mullis et al., 2004, p. 83). On the problem in fig. 10 the Dutch grade 8 students had the highest score from all participating countries; $97 \%$ of the Dutch students got a full credit for this number problem.

The second number problem we like to discuss here is about division by a fraction (see fig. 11). The problem is taken from the high international benchmark of mathematics achievement. Students reaching this benchmark are expected to "apply their understanding and knowledge in a wide variety of relatively complex situations. They can order, relate, and compute with fractions and decimals to solve word problems, operate with negative integers, and solve multi-step word problems involving

\footnotetext{
${ }^{20}$ Trend items are items that are included in both the 1999 and the 2003 TIMSS Studies.
} 
proportions with whole numbers” (Mullis et al., 2004, p. 75).

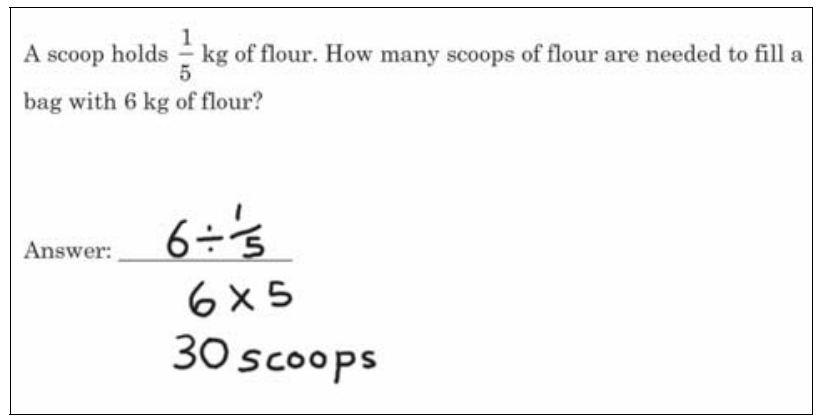

Fig. 11: Division by a fraction

(Mullis et. Al. 2004, p. 76).

Of the Dutch grade 8 students $74 \%$ got a full credit on the problem in fig. 11, while the international average was $38 \%$. This is a quite remarkable difference into which we like to go somewhat deeper now.

Of course, it is somewhat tricky to speculate about the source that causes this difference without having more information than only the percentage of correct answers, but nevertheless we think that we can explain the high score of the Dutch students.

The first explanation might be that Dutch students are experienced with context problems. As stated in the core goals for primary school of 1993/1998 the students can "compare, add, subtract, divide, and multiply simple fractions in simple context situations by means of models" (see Section 4.2.2). Moreover, a similar core goal is found in the core goals for primary school of 2004. They include that the students should learn "to understand in a general way the structure and relationships of [...] fractions [...] and are able to calculate with them in practical situations" (see Section 4.2.2). In the core goals for secondary school it is stated that "students should be able to perform simple calculations involving [...] fractions [...] by making use of mathematical models.” Also in secondary education attention is paid to number and in particular to rational number (see fig. 7a).

A second explanation for the large difference in scores might be go beyond the simple fact of being acquainted with these context problems. As the core goals indicate Dutch students might solve this fraction problem differently than other students. The specimen strategy released in the TIMSS report (see fig. 11) represents not the typical way in which Dutch students would solve this problem. Instead of carrying out the formal operation like:

$$
6 \div \frac{1}{5}=
$$

they will rather use a kind of informal, context-connected reasoning like:

$$
\begin{aligned}
& \text { I scoop holds } \frac{1}{5} \mathrm{~kg} \text {, } \\
& \text { so } 1 \mathrm{~kg} \text { is } 5 \text { scoops } \\
& \text { and } 6 \mathrm{~kg} \text { is } 6 \text { times } 5 \text {, is } 30 \text { scoops. }
\end{aligned}
$$

Another possible is that the Dutch students use a ratio table to find a solution (see fig. 12). This is a kind of basic tool/model to solve problems with rational numbers and proportions that originates from working within contexts.

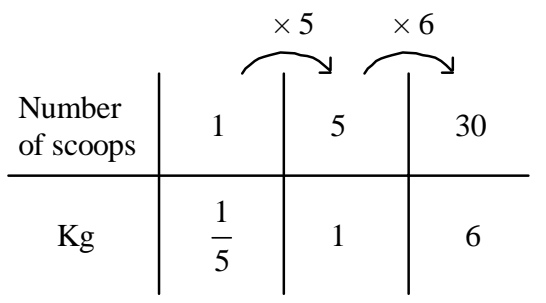

Fig. 12: Ratio table to solve a division by a fraction

By using transparent context-connected strategies, we think, a broad range of students has a better opportunity to solve difficult number problems such as division by a fraction-which is, in some way, confirmed by the score of the Dutch students on this problem in TIMSS. Another thing is that context-connected strategies provide students with a good foundation to come to more formal strategies. Starting at the formal level we would call, like Freudenthal (1973) did, an "anti-didactic inversion."

The last problem we like to discuss here is an algebra problem (see fig. 13). It is about sequence of figures consisting of squares divided into small of triangles. In part C students were asked to explain a way to find the number of triangles in the 50th figure without making a drawing or counting the triangles. To receive a full credit for this part of the problem, students had to show or explain how their answer was obtained by providing a general expression or an equation and by calculating the correct number of triangles for the 50th figure.

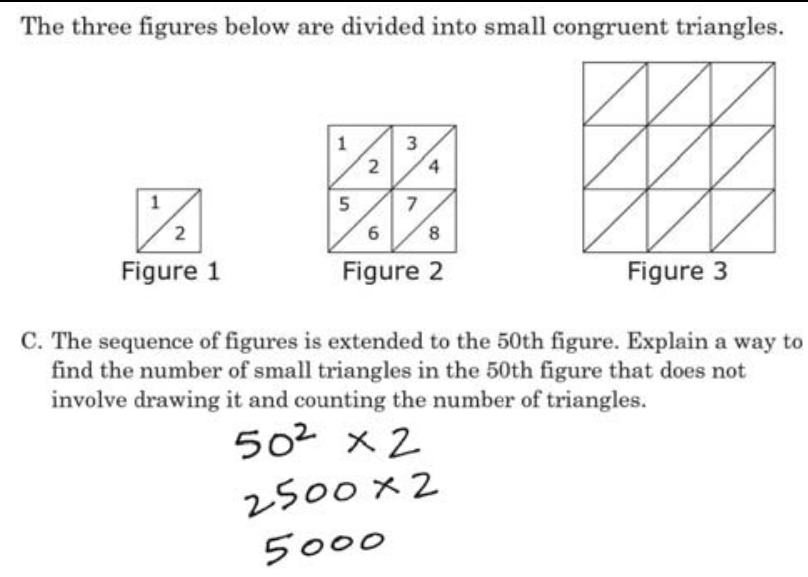

Fig. 13: Algebra problem

(Mullis et al., 2004, p. 72).

Internationally, this problem was among the most difficult ones in the TIMSS test. Only $14 \%$ of the students received a full credit for their response.

The score of the Dutch students was 36\%. Although we can just speculate here about the reasons for this relatively high score, we know that this type of problem is familiar to Dutch students: It can be found in Dutch textbooks. It fits the Dutch approach to algebra, were in the beginning informal methods are used to describe patterns and make generalization. Moreover, this TIMSS problem fits the following 1998 core goals: 
- Describe a simple relation between two real variables using an expression, a table, a graph or a (verbal) formula, or deduce such a relation from a description in any of these forms.

- Determine, express and project regularity in numeric patterns and tables.

Dutch students are also used to the fact that solutions may be found using several different methods. This problem refers to that aspect where it states: "Explain a way [...] that does not involve drawing it and counting te number of triangles” (see fig. 13). Furthermore Dutch students are used to write explanations. This fits one of the general objectives of the mathematics in the basic secondary educautions which is to have students acquire proficiency in the use of mathematical language as a means of communication.

Of course it is difficult to draw overall conclusions about the achievement of Dutch students based on only a few scores, but nevertheless we can say that both the relatively good results on the number problems and the relatively high score on the algebra problem has a rather strong relationship with what was offered in primary and secondary education-either thanks to the standards or despite of the standards.

\section{Concluding remarks}

A characteristic of the reform that has taken place in mathematics education in the Netherlands in the last three decades is that the change happened in a rather informal way. Although the Ministry of Education funded many curriculum reform projects, no prescriptions on content and didactical approach were provided. The moving force behind the reform movement was the strong community of mathematics educators, researchers and textbook authors, and the infra-structure of conferences and journals. As said earlier, the improvement of mathematics education was largely stimulated by the development of new textbooks and to date textbooks have an important role in determining the content of day to day teaching.

The core goals that have been formulated since 1993 elicited new discussions about what should be taught and certainly prompted textbook authors and test designers to include particular content in textbooks and tests. That these standards also have a role in guiding teachers directly is not very likely. For this, the core goals are too global and too vague. It is clear that we need learningteaching trajectories such as the TAL trajectories to bridge the gap between the global core goals and the detailed description of teaching activities as can be found in textbooks. Learning-teaching trajectories offer teachers a conceptual framework for didactical decision making.

These trajectories are now partly available for primary school, but they are lacking for secondary school. This is even true for the foundation phase of secondary school. Obviously, primary school and the foundation phase of secondary school are still two different worlds. Despite the similarities in the two lists of core goals, the global description of the core goals and the lack of an overall conceptual framework hinder the realization of a cohesive on-going development from primary school to secondary school. For example, in no way it is clear how the number strand and the early algebra strand are related to each other.

Another point of critique concerns the way in which content choices have been made as is reflected by the instable in-out pattern that characterizes the list of core goals. The foundations for these decisions are often unclear. As a consequence, apart from widening the scope in the sense of having a longitudinal focus that includes primary school and secondary school, we should also work on a better procedure for decision making when it comes to establishing core goals. Decisions about standards are not merely a political issue but should be grounded by domain-specific didactial research. In this area there is still much to do in the Netherlands.

\section{References}

Becker, J.P.; Jacob, B. (1998): Math War development in the United States (California). - In: ICMI Bulletin 44, June

Bereiter, C. (2002): Education and Mind in the Knowledge Age. - Mahwah, NJ: Lawrence Erlbaum Associates

Burton, L. (2002): Recognising commonalities and reconciling differences in mathematics education. - In: Educational Studies in Mathematics 50, p. 157-175

Cadot, J.; D. Vroegindeweij (1986): 10 voor de basisvorming onderzocht. - Utrecht: OW \& OC

Commissie Kerndoelen Basisonderwijs (Wijnen Committee) (2002): Verantwoording delen. Herziening van de kerndoelen basisonderwijs met het oog op beleidsruimte voor scholen. Zoetermeer: OCenW

De Wit, C.N.M. (1997): Over tussendoelen gesproken. Tussendoelen als component van leerlijnen [Talking about intermediate goals. Intermediate goals as a component of teaching/learning trajectories]. - 's-Hertogenbosch: KPC Onderwijs Innovatie Centrum

De Moor, E.W.A. (1999): Van Vormleer naar Realistische Meetkunde [A historical-didactic research into geometry teaching to children of four to fourteen years of age during the nineteenth and twentieth centuries in the Netherlands]. Utrecht University, Utrecht: CD-ß Press

Freudenthal, H. (1968): Why to Teach Mathematics so as to Be Useful. - In: Educational Studies in Mathematics 1, p. 3-8

Freudenthal, H. (1971): Geometry Between the Devil and the Deep Sea. - In: Educational Studies in Mathematics 3, p. 413-435

Freudenthal, H. (1973): Mathematics as an Educational Task. Dordrecht: Reidel Publishing Company

Freudenthal, H. (1977): Antwoord door Prof. Dr. H. Freudenthal na het verlenen van het eredoctoraat [Speech by Prof. $\mathrm{H}$. Freudenthal upon being granted an honorary doctorate]. - In: Euclides 52, p. 336-338

Freudenthal, H. (1979): Structuur der wiskunde en wiskundige structuren; een onderwijskundige analyse [Structure of mathematics and mathematical structures; an educational analysis]. - In: Pedagogische Studiën 56 (No. 2), p. 51-60

Freudenthal, H. (1987): Schrijf dat op, Hans. Knipsels uit een leven [Write that down, Hans. Clippings from a life]. Amsterdam: Meulenhof

Freudenthal, H. (1991): Revisiting Mathematics Education. China Lectures. - Dordrecht: Kluwer Academic Publishers

Hiebert, J. (1999): Relationships between research and the NCTM Standards. - In: Journal for Research in Mathematics Education 30 (No. 1), p. 3-19 
Inspectie van het Onderwijs (1999): Werk aan de basis. Evaluatie van de basisvorming na vijf jaar [Work at the basis. Evaluation of the basic education after five years]. - Utrecht, Inspectie van het onderwijs

Janssen, J.; Van der Schoot, F.; Hemker, B.; Verhelst, N. (1999): Balans van het reken-wiskundeonderwijs aan het einde van de basisschool 3. - Arnhem: Cito

Kilpatrick, J. (2001): Where is the evidence? - In: Journal for Research in Mathematics Education 32 (No. 4), p. 421-427

Klep. J. (Ed.) (2002): Beredeneerd Voorstel voor Aanpassing van de Kerndoelen Rekenen-wiskunde in het Basisonderwijs. - Enschede: SLO

Meelissen, M.R.M.; Doornekamp, B.G. (2004): TIMSS-2003 Nederland. Leerprestaties in exacte vakken in het voortgezet onderwijs. - Enschede: Universiteit Twente, Faculteit Gedragswetenschappen

Ministerie van Onderwijs en Wetenschappen (MOW) (1993a): Kerndoelen Basisonderwijs. - In: Gele Katern, Uitleg, 9, 18b, p. 3-19

Ministerie van Onderwijs en Wetenschappen (MOW) (1993b): Besluit kerndoelen basisonderwijs. - 's-Gravenhage: Sdu

Ministerie van Onderwijs, Cultuur en Wetenschappen (OCenW) (1998a): Kerndoelen basisonderwijs 1998. Over de relatie tussen de algemene doelen en kerndoelen per vak. - Den Haag: Sdu

Ministerie van Onderwijs, Cultuur en Wetenschappen (OCenW) (1998b): Attainment targets 1998-2003. Basic Secondary Education in the Netherlands. - Den Haag: Sdu

Ministerie van Onderwijs, Cultuur en Wetenschappen (OCenW), (2004): Voorstel Herziene Kerndoelen Basisonderwijs. - Den Haag: OCenW

Mullis, I.V.S.; Martin, M. O.; Gonzalez, E. J.; Chrostowski, S. J. (2004): TIMSS 2003 International Mathematics Report. Boston, TIMSS \& PIRLS International Study Center, Lynch School of Education, Boston College

Onderwijsraad (2001): De basisvorming: aanpassing en toekomstbeeld. - Den Haag, Onderwijsraad

Senk, S.L.; Thompson, D.R. (Eds.) (2003): Standards-Based School Mathematics Curricula. What are they? What do students learn? - Mahwah, NJ: Lawrence Erlbaum Associates

Streefland, L. (1985a): Wiskunde als activiteit en de realiteit als bron [Mathematics as an activity and reality as source]. - In: Nieuwe Wiskrant 5 (No. 1), p. 60-67

Streefland, L. (1985b): Vorgreifendes Lernen zum Steuern Langfristiger Lernprozesse [Anticipatory learning to steer long-term learning processes]. - In: W. Dörfler; R. Fischer (Eds.), Empirische Untersuchungen zum Lehren und Lernen von Mathematik. Beiträge zum 4. Internationalen Symposium für Didaktik der Mathematik in Klagenfurt in 1984. Wien: Hölder-Pichler-Tempsky, p. 271-285

Taakgroep Vernieuwing Onderbouw (2004a): Beweging in de onderbouw. Hoofdrapport. - Zwolle, Taakgroep Vernieuwing Onderbouw

Taakgroep Vernieuwing Onderbouw (2004b): Beweging in de onderbouw. Bijlagen. - Zwolle, Taakgroep Vernieuwing Onderbouw

Treffers, A. (1978): Wiskobas doelgericht [Wiskobas goaldirected]. - Utrecht: IOWO

Treffers, A. (1987): Three Dimensions. A Model of Goal and Theory Description in Mathematics Instruction-the Wiskobas Project. - Dordrecht: Reidel Publishing Company

Treffers, A.; de Moor, E. (1984): 10 voor de basisvorming rekenen/wiskunde (werkboek). - Utrecht: OW\&OC

Treffers, A.; de Moor, E.; Feijs, E. (1989): Proeve van een nationaal programma voor het reken- wiskundeonderwijs op de basisschool. Deel I. Overzicht einddoelen [Design of a national program for mathematics education in primary schools. Part I. Overview of goals]. - Tilburg: Zwijsen
Treffers, A.; de Moor, E. (1990): Proeve van een nationaal programma voor het reken-wiskundeonderwijs op de basisschool. Deel 2. Basisvaardigheden en cijferen [Design of a national program for mathematics education in primary schools. Part 2. Basic skills and algorithms]. - Tilburg: Zwijsen

Treffers, A.; Streefland L.; de Moor, E. (1994): Proeve van een nationaal programma voor het reken-wiskundeonderwijs op de basisschool. Deel 3A. Breuken [Design of a national program for mathematics education in primary schools. Part 3A. Fractions]. - Tilburg: Zwijsen

Treffers, A.; Streefland, L.; de Moor, E. (1996): Proeve van een nationaal programma voor het reken-wiskundeonderwijs op de basisschool. Deel 3B. Kommagetallen [Design of a national program for mathematics education in primary schools. Part 3B. Decimal numbers]. - Tilburg: Zwijsen

Treffers, A.; Van den Heuvel-Panhuizen, M.; Buys, K. (Eds.) (1999): Jonge kinderen leren rekenen. Tussendoelen annex leerlijnen. Hele getallen onderbouw basisschool. - Groningen: Wolters-Noordhoff

Van den Brink, F.J. (1989): Realistisch rekenonderwijs aan jonge kinderen. - Utrecht: OC\&OW, Rijksuniversiteit Utrecht

Van den Heuvel-Panhuizen, M. (1996): Assessment and realistic mathematics education. - Utrecht: CD-ß Press / Freudenthal Institute, Utrecht University

Van den Heuvel-Panhuizen, M.; Fosnot, C.T. (2001): Assessment of mathematics achievements: not only the answers count. - In M. van den Heuvel-Panhuizen (Ed.), Proceedings of the 25th conference of the international group for the psychology of mathematics education. Utrecht: Freudenthal Institute, Utrecht University, Volume 4, p. 335-342

Van den Heuvel-Panhuizen, M.; Buys, K.; Treffers, A. (Eds.) (2001): Kinderen leren rekenen. Tussendoelen annex leerlijnen. Hele getallen bovenbouw basisschool. - Groningen: Wolters-Noordhoff

Van den Heuvel-Panhuizen, M. (Ed.) (2001): Children Learn Mathematics. A Learning-Teaching Trajectory with Intermediate Attainment Targets for Calculation with Whole Numbers in Primary School. - Utrecht: Freudenthal Institute, Utrecht University / SLO

Van den Heuvel-Panhuizen, M.; Buys, K. (Eds.) (2004): Jonge kinderen leren meten en meetkunde. Tussendoelen annex leerlijnen. - Groningen: Wolters-Noordhoff

Van den Heuvel-Panhuizen, M.; Buys, K. (Eds.) (2005): Young Children Learn Measurement and Geometry. A LearningTeaching Trajectory with Intermediate Attainment Targets for the Lower Grades in Primary School. - Utrecht: Freudenthal Institute / SLO

Van den Heuvel-Panhuizen, M. (2003a): The didactical use of models in Realististic Mathematics Education: An example from a longitudinal trakectory on percentage. - In: Educational Studies in Mathematics 54 (No. 1), p. 9-35

Van den Heuvel-Panhuizen, M. (2003b): Die Geschichte der "Realistic Mathematics Education" anhand von Aufgaben erläutert. - In Ruwisch, S.; Peter-Koop, A. (Eds.), Gute Aufgaben im Mathematikunterricht der Grundschule. Offenburg: Mildenberger Verlag, p. 25-39

Van den Heuvel-Panhuizen, M. (2005): Can scientific research answer the 'what' question of mathematics education? - In: Cambridge Journal of Education 35 (No. 1), p. 35-53

Van der Wel, J.J.; Van der Vegt, A.L.; Van den HeuvelPanhuizen, M.; Nelissen, J. (2002): De implementatie van “Tussendoelen Annex Leerlijnen” (TAL). Een formatieve evaluatie. Eindrapport. - Amsterdam: Regioplan Onderwijs en Arbeidsmarkt

Wijdeveld, E.; Verhage, H.B.; Schoemaker, G. (2000): Van CMLW tot Freudenthal Instituut. - In: F. Goffree; M. van Hoorn; B. Zwaneveld (Eds.), Honderd jaar wiskundeonderwijs. Leusden: Nederlandse Vereniging van Wiskundeleraren, p.355-374. 
Wittmann, E.C. (1999): Konstruktion eines Geometriecurriculums ausgehend von Grundideen der Elementargeometrie. In: H. Henning (Ed.), Mathematik lernen durch Handeln und Erfahrung. Festschrift zum 75. Geburtstag von Heinrich Besuden. Oldenburg: Bültmann \& Gerriets, p. 205-223

\section{Authors}

Van den Heuvel-Panhuizen, Marja, Dr., Senior Researcher, Freudenthal Institute, Utrecht University, Aidadreef 12, 3561 GE Utrecht, the Netherlands; Visiting Professor (Wintersemester 2004/2005), Institut für Entwicklung und Erforschung des Mathematikunterrichts, Universität Dortmund, D-44221 Dortmund.

Email: m.vandenheuvel@fi.uu.nl

Wijers, Monica, Doctorandus., Researcher, Freudenthal Institute, Utrecht University, Aidadreef 12, 3561 GE Utrecht, the Netherlands.

Email: m.wijers@fi.uu.nl 